UNIVERSIDADE DE BRASÍLIA

\title{
ARTIGO 285-A DO CÓDIGO DE PROCESSO CIVIL: RACIONALIZAÇÃO E CELERIDADE OU INCONSTITUCIONALIDADE?
}

\author{
ELABORADA POR
}

GUSTAVO ALVES DA MATA GUIMARÃES

Brasília-DF, 2011. 


\section{UNIVERSIDADE DE BRASÍLIA}

\section{ARTIGO 285-A DO CÓDIGO DE PROCESSO CIVIL: RACIONALIZAÇÃO E CELERIDADE OU INCONSTITUCIONALIDADE?}

Monografia apresentada à Universidade de Brasília como requisito para conclusão do curso de direito.

Professor Orientador: Tarcísio Vieira de Carvalho Neto Mestre e Professor Assistente da UnB 
Aos meus pais, José Mário e lone, pelo zêlo e amor que sempre me proporcionaram e ao meu irmão Samuel, pelo braço amigo sempre pronto a ajudar. 


\section{RESUMO}

A presente monografia destina-se à análise da constitucionalidade do art. 285-A, o qual foi acrescentado ao Código de Processo Civil brasileiro por meio da Lei 11.277/2006. O dispositivo em comento foi concebido como instrumento de racionalização do julgamento de processos repetitivos e se insere dentro do robusto movimento de reformas do estatuto processual civil, destinadas à promoção de uma tutela jurisdicional mais efetiva. Muito embora venha em nome de um ideal nobre, a saber, a celeridade da prestação jurisdicional, o artigo 285-A é apontado como mecanismo potencialmente lesivo ao princípio do contraditório, da ampla defesa, do devido processo legal e ao direito de ação, os quais constituem direitos e garantias constitucionais do processo judicial. A pesquisa aborda a importância do princípio da celeridade para promoção de uma justiça realmente efetiva. Ao mesmo tempo, reconhece que esse princípio não é absoluto, devendo ser compatibilizado com os demais princípios e garantias que orientam o direito processual. O estudo prossegue com a apresentação das principais alterações promovidas no Código de Processo Civil e das tendências que tem orientado o seu desenvolvimento. Por fim, dedica-se especial atenção a cada uma das alegações de inconstitucionalidade do dispositivo, procurando verificar a viabilidade de preservação do preceito normativo, dos benefícios a que ele se destina, bem como dos demais princípios conformadores do direito processual. Palavras-chave: Jurisdição, direito de acesso à justiça, ondas do direito de acesso à justiça, efetividade da tutela jurisdicional, morosidade, reformas do Código de Processo Civil, tendências do processo civil contemporâneo, Lei 11.277, art. 285-A, racionalização, celeridade, (in)constitucionalidade, direito de ação, devido processo legal, ampla defesa, contraditório.

\section{ABSTRACT}

This monograph is intended to do the analysis of the constitutionality of article 285-A, which was added to the Brazilian Code of Civil Procedure by Law $11277 / 2006$. The article 285-A was designed as a tool for streamlining the trial of repetitive processes and is inserted in the robust movement to reform the Code of Civil Procedure, aimed to promote a judicial protection more effective. Despite his noble ideal of promoting celerity in judicial procedure, the article $285-\mathrm{A}$ is identified as a potentially harmful mechanism to the principles of contradictory, ample defense, due process of law and right of action, which are constitutional rights and guarantees of judicial proceedings. The research enhance the importance of the principle of celerity in the promotion of a really effective judicial protection. At the same time recognizes that this principle is not absolute and must be harmonized with the other principles and assurances that guide the procedural law. The study continues with the presentation of the main changes introduced in the Code of Civil Procedure and the trends that has guided its development. Finally, special attention is devoted to each one of the claims of unconstitutionality relative to the article 285-A, trying to verify the feasibility of preserving the legal precept, the benefits to which it is intended, as well as other principles of procedural law. Keywords: Jurisdiction, right of access to justice, stages of the right of access to justice, effective in jurisdictional provision, slowness, reforms of the code of civil procedure, contemporary trends in civil procedure, Law 11277, article 285-A, streamlining, celerity, (un)constitutionality, right action, due process of law, ample defense, contradictory. 


\section{LISTA DE SIGLAS}

ADI - Ação Direta de Inconstitucionalidade

BNDPJ - Banco Nacional de Dados do Poder Judiciário

CDC - Código de Defesa do Consumidor

CF - Constituição da República Federativa do Brasil de 1988

CPC - Código de Processo Civil

EC - Emenda Constitucional

RE - Recurso Extraordinário

STJ - Superior Tribunal de Justiça

STF - Supremo Tribunal Federal 


\section{Sumário}

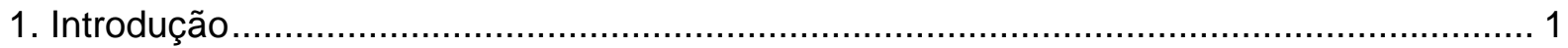

2. O direito de acesso à justiça, a efetividade da jurisdição e a celeridade da tutela

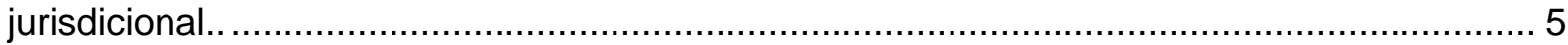

3. A morosidade do Poder Judiciário brasileiro e a busca incessante por uma jurisdição mais

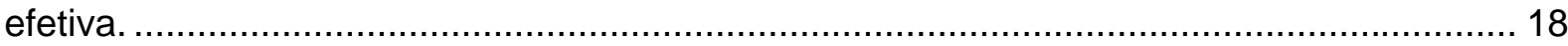

4. O artigo 285-A do Código de Processo Civil e o debate acerca da sua constitucionalidade. 33

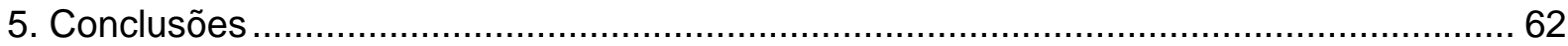

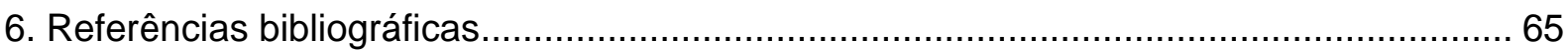




\section{Introdução}

O artigo 285-A foi inserido no Código de Processo Civil em 2006 por força da Lei 11.277 e, desde então, despertou - entre os juristas, doutrinadores e operadores do direito - inúmeras discussões sobre sua constitucionalidade. Não faltam polêmicas em torno desse tema, cuja matéria é deveras instigante e fecunda. Além disso, a definição acerca da constitucionalidade ou inconstitucionalidade do mencionado dispositivo está na ordem do dia. Neste particular, o Conselho Federal da Ordem dos Advogados do Brasil ajuizou ação direta de inconstitucionalidade contra a íntegra da Lei 11.277/06 (ADI 3695-5), que está pendente de julgamento pelo Supremo Tribunal Federal.

O artigo 285-A, caput do CPC permite que o juiz - ao verificar que a matéria submetida a sua apreciação é unicamente de direito e que no juízo já foi proferida sentença de total improcedência em outros casos idênticos - dispense a citação do réu e reproduza a sentença anteriormente prolatada.

Com essa disposição, o artigo busca conferir maior racionalidade e celeridade à atividade jurisdicional, passando-se diretamente à prolação de uma sentença sem se deter em atos processuais considerados dispensáveis pelo legislador, como a apresentação de resposta pelo réu e de réplica pelo autor.

O ponto de chegada da presente monografia será a tomada de um posicionamento acerca da constitucionalidade ou inconstitucionalidade do dispositivo. Entretanto, para chegarmos ao ponto áureo da pesquisa, será necessário percorrer todo um caminho, que criará um contexto propício para as discussões que se apresentarão. 
Inicia-se apresentando o Estado como ente ao qual foi atribuído o exercício da função de promover a justiça, em substituição aos particulares, que, originariamente, buscavam por conta própria tutelar seus interesses, valendo-se dos meios disponíveis para a sua consecução (justiça privada).

Aos indivíduos, agora destituídos da faculdade de realizar a justiça com as próprias mãos, foi conferido o direito de acesso à justiça. O Estado, por sua vez, além do poder terá o dever de prestar a jurisdição ao particular, sempre que chamado a exercê-la. Outrossim, a tutela jurisdicional deverá ser prestada com celeridade e efetividade, facultando-se a todos a utilização de instrumentos processuais adequados à tutela pretendida. Sem isso, não se poderia falar em direito de acesso à justiça.

O trabalho prossegue com a apresentação das três ondas do direito de acesso à justiça, na célebre formulação teórica de Mauro Cappelletti, e descortina os principais aspectos das recentes leis que promoveram alterações no Código de Processo Civil, ícones por demais evidentes do atual momento histórico, que se caracteriza pela busca incessante de uma jurisdição mais célere e efetiva.

Sem a pretensão de esgotar o tema, são reveladas as grandes alterações do estatuto processual civil. São tantas as modificações promovidas nesse diploma normativo nos últimos anos que - para compreender melhor o modo como o direito processual vem se desenvolvendo e os rumos pelos quais haverá de seguir -, decidiu-se, num esforço de sistematização, enquadrá-las em algumas tendências de desenvolvimento do processo civil contemporâneo, de que são exemplos, dentre outras: a simplificação dos procedimentos, a informatização do processo judicial, o fortalecimento dos poderes dos magistrados, a crescente valorização da jurisprudência como fonte do direito e a instrumentalização do processo. 
Dentre as recentes alterações promovidas no Código de Processo Civil, põe-se em relevo o artigo 285-A, e, daí em diante, o trabalho passa a analisar as principais alegações de inconstitucionalidade dirigidas a esse dispositivo.

Uma das críticas lançadas contra o dispositivo diz respeito à própria possibilidade de proferimento de sentença liminar de improcedência. Desse ato judicial, para alguns doutrinadores, resultaria desarrazoada restrição ao direito de ação e flagrante violação do princípio do contraditório.

Podem-se mencionar ainda como óbices à constitucionalidade do dispositivo: (a) a circunstância de o magistrado tomar sentença de total improcedência proferida no seu próprio juízo como parâmetro para solução de centenas de outros casos "idênticos" que lhe forem submetidos, ao invés de fundamentar sua decisão em entendimento mais sólido, consubstanciado em súmula ou jurisprudência dominante dos tribunais que lhe são hierarquicamente superiores; (b) a ausência de previsão de comunicação do réu, na hipótese de a sentença proferida in limine litis transitar em julgado pela não interposição de apelação por parte do autor; e (c) a circunstância de o réu/apelado ser citado apenas para responder ao recurso de apelação (art. 285-A, $\S 2^{\circ}$ ) e não para oferecer resposta à petição inicial por meio da qual o réu poderia apresentar toda a matéria disponível para sua defesa sob as mais diversas formas (contestação, exceção, reconvenção, impugnação ao valor da causa, impugnação ao benefício da assistência judiciária gratuita).

Por tudo isso, há doutrinadores que defendem que o procedimento previsto no art. 285-A do CPC, hoje conhecido como "julgamento super-antecipado da lide", macula a prestação jurisdicional, porquanto viola o direito de ação, o princípio constitucional do contraditório, da ampla defesa e do devido processo legal. 
Essas palpitantes discussões constituem o ensejo da presente monografia. 


\section{O direito de acesso à justiça, a efetividade da jurisdição e a celeridade da tutela jurisdicional.}

O homem, como se sabe, é um ser gregário, social. A grande capacidade que os seres humanos possuem para se relacionar e se comunicar é uma forte evidência dessa afirmação. A vida em grupos, clãs, tribos, desde os tempos mais remotos, sempre foi mais propícia à sobrevivência e ao desenvolvimento das potencialidades dos seres humanos que a vida solitária. A propósito, José Eduardo Carreira Alvim, ensina que "cada homem tem necessidade dos demais para sua conservação e aperfeiçoamento, pelo que a sociedade não é uma formação artificial, mas uma necessidade natural do homem."1

Não se deve ignorar, porém, que o relacionamento entre aqueles que integram um determinado grupo deve ser harmonioso, sob pena de se por em xeque a utilidade da convivência em conjunto. Cada integrante do grupo deve entender que os interesses individuais, por vezes, concorrem para um objetivo comum, mas em outras se chocam. Em virtude disso, é necessário o estabelecimento de regras que disciplinem de forma racional e sensata a conduta de cada membro nos relacionamentos intersubjetivos, a fim de evitar conflitos e solucionar aqueles que eventualmente se manifestarem. Essa providência implica, em alguma medida, a limitação da liberdade individual dos membros do grupo, mas é absolutamente necessária à coesão da unidade social e convivência harmoniosa. Como diz o ditado popular "o direito de cada um vai até onde começa o de outrem".

Pode-se dizer, assim, que, dentro de um grupo, espontaneamente, nascem regramentos que se destinam a regular o comportamento dos integrantes 
do corpo social e isto é extremamente importante para a convivência intersubjetiva, porquanto confere ordem à vida em sociedade. Esta conclusão é por demais conhecida e vem muito bem expressa naqueles antigos brocardos latinos: "ex facto oritur jus" e "ubi societas ibi jus"2.

O Estado é o responsável por estabelecer a ordem jurídica e exerce esta atividade por meio da função legislativa. Inicialmente, incumbia ao próprio particular, titular de um direito reconhecido pelo Estado e violado por outrem, tutelá-lo. A justiça era, portanto, realizada pelos próprios particulares (justiça privada), que promoviam as atividades necessárias a fazer prevalecer a sua posição jurídica de vantagem.

A autotutela dos direitos, naturalmente, não se revelou como meio idôneo a promover a pacificação social, porque em resposta à ação daquele que se sentiu lesado em algum direito sempre havia a possibilidade de que a outra parte, sentindose prejudicada ou movendo-se por um sentimento vingança, agisse em represália, o que poderia levar à eternização dos conflitos e a criação de um estado latente de insegurança.

Desse modo, verificada a inaptidão da justiça privada em promover a adequada resolução dos conflitos, atribuiu-se o exercício da função jurisdicional ao Estado, que, portanto, acumulou o encargo e o monopólio de definir o direito concretamente aplicável diante das situações litigiosas (função legislativa), bem como o de realizar esse mesmo direito se a parte recalcitrante recusar-se a cumprir espontaneamente o comando concreto da lei (função jurisdicional). ${ }^{3}$

\footnotetext{
2 Em vernáculo, respectivamente: "Do fato origina-se o direito" e "Onde há sociedade há direito". 
Se, por um lado, foi retirada dos particulares a faculdade de realizar a justiça com as próprias mãos ${ }^{4}$, por outro foi constituída a garantia da prestação jurisdicional pelo Estado. Precisamente, aqui, se encontra o fundamento do direito de acesso à justiça.

Com efeito, ao assumir o encargo de prestar a jurisdição em substituição às partes envolvidas no litígio, o Estado não pode furtar-se de realizá-la. Como bem destacou Pontes de Miranda, aquele que busca o Estado, desencadeando o exercício da jurisdição, é titular de uma pretensão à obtenção da prestação jurisdicional - resposta ao reclamo daquele que busca ver tutelado um direito em tese existente. ${ }^{5}$

Desse modo, o Estado, chamado ao exercício da jurisdição, passa a ter o dever de prestá-la no caso concreto submetido à sua apreciação. Outrossim, o direito de acesso à justiça não pode ser restringido abstratamente pelo Estado. Admitir-se isto, seria o mesmo que conferir permissão ao Estado para eximir-se de cumprir a atividade jurisdicional por meio da função legislativa. Tal garantia encontra guarida na Constituição Federal de 1988, que prevê em seu artigo 5º, inciso XXXV, o princípio da inafastabilidade da jurisdição, in verbis: "Art. $5^{\circ}$ (...) XXXV - a lei não excluirá da apreciação do Poder Judiciário lesão ou ameaça a direito."

O direito de acesso à justiça garante a toda pessoa (natural ou jurídica, de direito público ou de direito privado, detentora de boa condição financeira ou hipossuficiente do ponto de vista econômico, individual ou coletiva) e, inclusive, a alguns entes despersonalizados a quem a lei atribui capacidade para ser parte (tais como a massa falida, o condomínio e o espólio), o acesso aos órgãos do Poder

\footnotetext{
${ }^{4}$ No ordenamento jurídico brasileiro, ressalvadas hipóteses excepcionais previstas em lei (como o desforço imediato para tutela da posse, previsto no art.1.210, § $1^{\circ}$, do Código Civil), a autotutela é considerada crime, estando tipificada no artigo 345 do Código Penal, que prevê o delito de exercício arbitrário das próprias razões.

${ }^{5}$ MIRANDA, Pontes de (1996, p. 79).
} 
Judiciário com instrumentos processuais adequados para tutela dos direitos individuais e também dos transindividuais (difusos e coletivos, conceituados no artigo 81, parágrafo único, incisos I e II do Código de Defesa do Consumidor) ${ }^{6}$.

Evidentemente, a tutela jurisdicional deve ser efetiva. De nada adiantaria à parte ter o direito de acesso à justiça, se o Estado revelar-se incapaz de dar um provimento jurisdicional que faça atuar, no caso concreto, a vontade da lei. Por jurisdição efetiva entende-se aquela que é capaz de compor os litígios com justiça e celeridade $^{7}$, promovendo a paz social.

Oportuno frisar que o termo "justiça" aqui empregado não se confunde com o ideal utópico de obtenção e execução de uma decisão perfeita, inabalável. Entende-se como justa a composição dos litígios que respeita os ditames constitucionais e legais do processo e faz valer, no caso concreto, o direito material vigente, concebido em conformidade com o procedimento previsto, materialmente razoável e capaz de atender aos anseios sociais.

Acerca da efetividade da tutela jurisdicional, confira-se a lição de Teori Albino Zavascki:

O direito à efetividade da jurisdição - que se denomina também, genericamente, direito de acesso à justiça ou direito à ordem jurídica justa consiste no direito de provocar a atuação do Estado, detentor do monopólio da função jurisdicional, no sentido de obter, em prazo adequado, não apenas uma decisão justa, mas uma decisão com potencial de atuar eficazmente no plano dos fatos. ${ }^{8}$

\footnotetext{
${ }^{6}$ Há doutrinadores, como Misael Montenegro Filho, que incluem os direitos individuais homogêneos - conceituados no artigo 81, parágrafo único, III do CDC - como espécie dos direitos transindividuais (MONTENEGRO FILHO, Misael; 2007; p. 173). Outros doutrinadores, de que é exemplo Humberto Theodoro Júnior, verificando a possibilidade de fracionamento do interesse, preferem qualificar os direitos individuais homogêneos como direitos de titularidade individual, que, em face da especial circunstância de serem muito numerosas as pessoas que se encontram na mesma situação fático-jurídica, podem ser tutelados coletivamente através de órgãos ou entidades que atuam em nome do conjunto de interessados (THEODORO JÚNIOR, Humberto; 2009; p. 43). Neste particular, consideramos mais adequado o entendimento deste último autor. De todo modo, independentemente da classificação que seja adotada, o importante é ter em mente que a tutela dos direitos individuais homogêneos, que pode ser requerida e concedida de forma coletiva, constitui um instrumento importante de efetivação do direito de acesso à justiça.

${ }^{7}$ A rigor, o atributo "celeridade" não precisaria ser explicitado nesta definição, porquanto, a nosso sentir, já está embutido dentro do conceito "justiça". Contudo, preferiu-se deixá-lo expresso para colocá-lo em destaque, realçando, desse modo, o valor de um conceito que é de fundamental importância, no presente trabalho monográfico.

${ }^{8}$ ZAVASCKI, Teori Albino (1997, p. 32).
} 
Como visto acima, o titular de uma posição jurídica de vantagem, para obter o bem da vida que almeja deve requerer a prestação da atividade jurisdicional, que é exercida por meio do processo. Este, para que se revele como instrumento idôneo à composição dos litígios e à promoção da paz social, há de ser conduzido da forma devida. Em outras palavras, cada processo deve obedecer ao procedimento que Ihe é aplicável e cuja disciplina está disposta nas leis processuais. Deve, ainda, sobretudo, sujeitar-se às normas constitucionais que o regulam, principalmente aos princípios e garantias constitucionais do processo, os quais norteiam toda a conformação do sistema processual, estabelecendo as premissas para o seu funcionamento. A essa exigência de obediência dos princípios e das regras constitucionais e legais que regulam o processo, dá-se o nome de princípio do devido processo legal em sentido processual ou procedural due process of Law.

Inicialmente, o princípio do devido processo legal foi concebido como tendo um caráter exclusivamente processual, ou seja, de exigência de um procedimento adequado, afinado com as normas constitucionais e legais e dotado de técnicas processuais aptas a fazer atuar a vontade da lei. Todavia, hoje, tem-se entendido que esta é apenas uma das facetas do devido processo legal, que guardaria também um caráter de direito material, denominado de substantive due process of law e que reflete a necessidade de a sociedade de ser submetida apenas a leis razoáveis. Sintetizando na expressão utilizada por Alexandre Freitas Câmara, o substantive due process of law pode ser considerado como o próprio princípio da razoabilidade das leis. ${ }^{9}$ Com efeito, ainda que seja respeitado o devido processo legal em sentido processual, se o direito material não for razoável, a tutela jurisdicional jamais será efetiva e capaz de atender aos anseios sociais. Destarte, 
não há como escapar da necessidade de reconhecer estas duas facetas do princípio do devido processo legal.

A celeridade da prestação jurisdicional é atributo imanente e indissociável do conceito de jurisdição efetiva, tal como o devido processo legal. De fato, não se pode conceber uma justiça morosa como efetiva. O sentido reparador da atividade jurisdicional é tanto menor quanto mais demorada for a sua prestação àquele que teve um direito violado, o qual, não raras vezes, tem de suportar por anos a fio a lesão perpetrada assim como os custos materiais e morais de um processo moroso. Em muitos casos, a demora do processo pode inviabilizar o acesso à justiça, como bem adverte Luciana de Oliveira Leal:

A longa duração do processo encarece em demasia uma postulação, servindo de desincentivo a grande parte dos indivíduos que não pode arcar com os custos de um processo prolongado, quer os devidos ao Estado, quer os necessários a contratação de advogados para a obrigatória (na maioria dos casos) assistência judiciária. ${ }^{10}$

Por um lado, a celeridade da prestação jurisdicional é um valor a ser buscado; tanto é assim que, em 2004, por meio da EC $n^{0} 45$, o constituinte acrescentou o inciso LXXVIII ao art. $5^{\circ}$ da Constituição Federal, cuja redação é a seguinte: "LXXVIII - a todos, no âmbito judicial e administrativo, são assegurados a razoável duração do processo e os meios que garantam a celeridade de sua tramitação"11.

Por outro lado, não se pode olvidar que o processo judicial passa por fases até que Ihe seja dada solução definitiva. Evidentemente, a observância do

\footnotetext{
${ }^{10}$ LEAL, Luciana de Oliveira (2005, p. 43-44).

${ }^{11}$ A rigor, o princípio da celeridade já integrava o ordenamento jurídico brasileiro, antes mesmo que o constituinte viesse deixálo expresso na Carta Magna. Em verdade, o princípio da celeridade já estava implícito no direito brasileiro, porque decorre do próprio direito de acesso à justiça e da idéia de efetividade da jurisdição. Foi adicionado à Lei Maior num momento em que o processo civil brasileiro revelava-se assaz carente de reformas que lhe conferissem mais celeridade. A inserção do princípio da celeridade à Constituição Federal, embora não tenha importado na sua criação, serviu para deitar luzes sobre o problema da morosidade judiciária e a necessidade de adoção de medidas concretas para sua superação.
} 
procedimento (que é criado para tornar efetivos os direitos e garantias processuais das partes) exige tempo.

A cada ato dos sujeitos processuais (autor, réu e juiz), tais como a elaboração de defesa, réplica ou recurso, a produção de provas, a prolação de despachos, decisões interlocutórias ou sentença, por exemplo, deve ser concedido um prazo razoável à sua realização. Isso é absolutamente necessário, sob pena de se negar às partes a adequada participação no processo e de não se propiciar ao magistrado o tempo necessário à prolação de uma decisão coerente, afinada com as questões de fato e de direito atinentes à lide e fundamentada nas normas jurídicas vigentes. Como bem sintetiza Luiz Guilherme Marinoni, "o tempo é uma necessidade do juiz, que dele precisa para formar a sua convicção, assim como uma necessidade democrática, advinda do direito de as partes participarem adequadamente do processo."12

Daí porque a bandeira da celeridade não deve ser alçada a todo custo, a ponto de lesar direitos e garantias das partes no processo judicial e exigindo decisão apressada e prematura do magistrado.

O princípio da celeridade encontra, pois, limites no princípio do devido processo legal. Talvez por isso, o constituinte, ciente de que o princípio da celeridade não pode ser buscado com sacrifício ou dano aos demais princípios norteadores do direito processual, ao elaborar a redação do inciso LXXVIII do artigo $5^{\circ}$ da Carta Magna, tenha dado maior ênfase no princípio da "duração razoável do processo" do que no da "celeridade". De todo modo, como bem assevera Luiz 
Guilherme Marinoni, ao magistrado cabe o dever de, respeitando os direitos de participação das partes, dar a máxima celeridade ao processo. ${ }^{13}$

Ao Poder Judiciário, portanto, foi atribuída uma árdua missão - que, em última análise, decorre do próprio direito de acesso à justiça -, qual seja: compor as inúmeras lides que Ihe são submetidas diariamente da forma devida (devido processo legal em sentido processual), com celeridade e sem descurar da qualidade $^{14}$ das decisões, que é exigida da atividade jurisdicional.

O direito de acesso à justiça não nasceu nos exatos termos como é concebido nos dias hodiernos. O nobre jurista italiano, Mauro Cappelletti, observou um movimento mundial de ampliação deste direito. Segundo o autor, pode-se identificar, no desenrolar histórico, três ondas de acesso à justiça ${ }^{15}$.

Historicamente, o direito processual tradicional, inspirado pela filosofia e valores liberais, foi concebido como instrumento destinado à composição dos litígios entre indivíduos que disputam entre si um determinado bem da vida. O direito de ação e os instrumentos processuais para a defesa do direito material em juízo, por esse motivo, foram arquitetados à luz da individualidade de um sujeito ativo e um sujeito passivo.

Esse caráter originário do direito processual, de nítidas feições individualistas, não se revelou capaz de garantir o acesso à justiça a todos os integrantes do corpo social, nem mesmo de tutelar toda ordem de bens e direitos que merecem proteção pelo ordenamento jurídico. As ondas do direito de acesso à

\footnotetext{
${ }^{13}$ MARINONI, Luiz Guilherme (2009, p. 316).

14 O termo "qualidade" aqui empregado não diz respeito à prolação de uma decisão com elevado grau de erudição. Refere-se sim, à produção de uma decisão que esteja atenta às circunstâncias de cada caso concreto, que aprecie as questões de fato e de direito presentes nos autos (art. 131 do CPC) e que esteja consciente dos resultados que produzirá na sociedade. Aliás, o objetivo da tutela jurisdicional nunca foi o de se obter uma decisão pela decisão, mas o de dar a cada um o que é seu, na célebre acepção de Giuseppe Chiovenda, para quem o processo deve dar na medida do possível a quem tem um direito, tudo aquilo e exatamente aquilo que ele tem direito de conseguir. A decisão judicial, portanto, jamais deve ser vista como uma obra de arte, mas como instrumento útil à efetivação do direito material.

${ }^{15}$ Este enfoque inovador que, posteriormente, recebeu grande recepção na doutrina brasileira, pode ser conferido na obra: CAPPELLETTI, Mauro e GARTH, Bryant. Acesso à Justiça; tradução e revisão de Ellen Gracie Northfleet, Porto Alegre: Sérgio Antonio Fabris Editor, 2002.
} 
justiça surgiram e se desenvolveram à medida que se verificava a inadequação do direito processual às necessidades do novos tempos.

A respeito desse tema, cumpre esclarecer que os institutos são concebidos e criados para o alcance dos fins que se deseja atingir. Naturalmente, com o passar do tempo e diante de novas necessidades sociais, os institutos podem revelar-se inadequados à realidade do novo momento histórico, pelo que se pode dizer, com segurança, que estão continuamente sujeitos a aprimoramentos e adaptações, sempre no intuito de concretizar com mais eficiência os fins almejados. Isto também ocorreu com o direito processual, que seguiu um caminho próprio de desenvolvimento, conforme se verá a seguir.

Como é cediço, o exercício do direito de ação (que é uma faceta do direito de acesso à justiça) requer o dispêndio de recursos financeiros como, por exemplo, o pagamento de honorários de advogados e de peritos, de taxas judiciárias e selos, de custas iniciais e finais, de emolumentos, de depósitos previstos em lei para interposição de recursos ou ajuizamento de ação, de despesas com publicações em jornais de circulação local, com a produção de provas, etc.

Sem dúvida, o gasto material para promoção e condução do processo judicial pode constituir um grande obstáculo ao acesso à justiça, principalmente às pessoas mais carentes. Daí porque, é necessário garantir assistência judiciária gratuita a todos aqueles que não podem arcar com os gastos decorrentes do processo judicial sem prejuízo do próprio sustento ou de sua família.

O direito à assistência judiciária gratuita aos necessitados deve ser entendido, portanto, como parte integrante do direito de acesso à justiça, sem o que este último não teria efetividade para boa parcela da população. Tal direito, contudo, não existiu ab initio, nos ordenamentos jurídicos dos países. Pelo contrário, pode ser 
considerado uma conquista histórica. Dentro do modelo teórico sugerido por Mauro Cappelletti, a busca e o subseqüente reconhecimento do direito à assistência judiciária gratuita constituiu a primeira onda de acesso à justiça.

No ordenamento jurídico brasileiro, em particular, o direito ora em exame vem consagrado no art. $5^{\circ}$, LXXIV da Carta Magna sob o status de cláusula pétrea e é regulado pela Lei 1.060 de 5 de fevereiro de 1950.

Com efeito, foi por meio do instituto da assistência judiciária gratuita que se estendeu o direito de acesso à justiça - outrora restrito àqueles que detinham condições de arcar com as despesas processuais - aos necessitados. Contudo, como adverte Alexandre Freitas Câmara, "embora todos pudessem levar suas demandas e pretensões ao Judiciário, qualquer que fosse sua situação econômica, nem todos os interesses e posições jurídicas de vantagem eram ainda passíveis de proteção através da tutela jurisdicional."16

A ampliação, o desenvolvimento e a complexificação das relações em sociedade bem como a preocupação com a tutela de novos direitos fez a comunidade jurídica perceber que a garantia da assistência judiciária gratuita, apesar da sua enorme importância, não seria capaz de promover, sozinha, o pleno acesso à justiça.

Faltava ao direito processual dar um importante passo rumo à concretização do direito de acesso à justiça, a saber: reconhecer, ao lado dos direitos pertencentes ao indivíduo singularmente considerado, novos direitos, cuja titularidade ultrapassa a esfera individual, alcançando toda a comunidade ou porções dela.

${ }^{16}$ CÂMARA, Alexandre Freitas (2009, p. 37). 
O caráter marcadamente individualista do direito processual, a partir de então, começou a ser moldado e progressivamente foram sendo incorporados aos ordenamentos jurídicos dos países instrumentos para a defesa desses novos direitos, cuja titularidade é coletiva ou difusa, os assim chamados direitos transindividuais.

Dentro desse panorama histórico, o Brasil - cujo ordenamento jurídico assegura a defesa de qualquer interesse difuso ou coletivo (art. $1^{\circ}$, IV da Lei 7.347/1985), dentre os quais é possível destacar a preservação do meio ambiente, a probidade administrativa, a proteção do patrimônio púbico, do consumidor, da ordem urbanística, da infância e juventude, do idoso, do portador de deficiência física, da ordem econômica, da economia popular, dos bens e direitos de valor artístico, estético, histórico, turístico e paisagístico - vem ocupando posição de destaque. Alguns doutrinadores chegam a afirmar que "o Brasil, nesse campo, exerce notória posição de liderança em nível mundial, sendo o país que, sem sobra de dúvida, conta com o maior número de instrumentos aptos a proteger tais interesses, como a ação popular, a ação civil pública, a ação civil coletiva e o mandado de segurança coletivo". 17

Conquistados os direitos transindividuais através deste movimento de ampliação da tutela jurisdicional, hoje comumente designado de segunda onda do direito de acesso à justiça, surgiu a importante indagação de se saber se as duas primeiras ondas renovatórias do direito processual seriam por si só suficientes a garantir uma prestação jurisdicional efetiva.

As duas primeiras fases do direito de acesso à justiça estão afinadas com o propósito de assegurar a todo sujeito de direito (economicamente hipossuficiente 
ou não, individual ou coletivo) titular de uma posição jurídica de vantagem a faculdade de acionar o Estado-juiz para obter um provimento jurisdicional favorável. De outra sorte, a efetividade da jurisdição, como visto no tópico anterior, vai além da mera faculdade de acionar o Poder Judiciário; diz respeito, precisamente, à obtenção do direito vindicado, a qual deve ocorrer em tempo razoável e sem dispensar, evidentemente, a observância das normas procedimentais e dos princípios constitucionais e legais que orientam o processo judicial.

Daí porque a resposta àquele questionamento há de ser negativa. Para desfrutar de uma jurisdição efetiva, além da faculdade de provocar a atuação estatal, o jurisdicionado deve ter a sua disposição instrumentos processuais adequados à efetivação do direito material e contar com um Poder Judiciário capacitado para exercer a sua missão institucional. Neste ponto, surge outra indagação: está o jurisdicionado satisfeito com a tutela jurisdicional? Sem dúvida, o Poder Judiciário brasileiro e dos demais países, ainda tem de dar passos importantes para que a jurisdição seja considerada realmente satisfatória.

Atualmente, a grande preocupação da comunidade jurídica tem sido a criação de instrumentos processuais (e também, é claro, o aprimoramento dos já existentes) que promovam a efetividade da tutela jurisdicional. Como alude Bruno Freire e Silva "a ciência processual contemporânea desvinculou-se de seu antigo perfil estático e individualista e atualmente está voltada para a busca da efetividade da tutela jurisdicional, que consiste na utilidade prática do processo, isto é, que ele tenha resultados úteis."18

Surge assim, a terceira onda do direito de acesso à justiça, que, no caso brasileiro, como veremos mais adiante, é marcada pelo surgimento de inúmeras leis 
promotoras de diversas reformas no Código de Processo Civil, tendentes à conformação de um direito processual que faça valer, com celeridade, a vontade do direito material no caso concreto. 


\section{A morosidade do Poder Judiciário brasileiro e a busca incessante por uma jurisdição mais efetiva}

Muito se tem falado sobre a morosidade da justiça brasileira. De há muito que a mídia e boa parcela dos jurisdicionados dirigem críticas ao Poder Judiciário acerca da demora na prestação jurisdicional. A imagem deste Poder (e, via de conseqüência, dos serventuários da justiça também) como Poder constituído para promover a justiça encontra-se um tanto desgastada para grande parte população.

De fato, há que se reconhecer que a falta de celeridade na prestação jurisdicional é um grave problema do Poder Judiciário brasileiro ${ }^{19}$, talvez, sem muito exagero, o maior deles e, como sobejamente visto, atinge a própria efetividade da tutela jurisdicional.

A lentidão do Poder Judiciário, entretanto, não pode ser atribuída aos magistrados e servidores, como muitas vezes pressupõe o senso comum. Esta idéia, que parece integrar o imaginário das pessoas comuns, é fruto do desconhecimento do volume exagerado de serviço que diariamente chega aos tribunais.

Com efeito, a demora da prestação jurisdicional tem raízes muito profundas; é um problema estrutural cuja solução depende da adoção de medidas concretas voltadas para a ampliação da estrutura material e de pessoal do Poder Judiciário e da criação de instrumentos processuais e tecnológicos que permitam a condução da atividade judicial de forma mais ágil e menos burocrática.

Uma das grandes causas da morosidade da justiça brasileira é o reduzido número de juízes. Em pesquisa realizada pelo Banco Mundial $^{20}$, pode-se verificar

\footnotetext{
${ }^{19}$ Frise-se, por oportuno, que não é um problema exclusivamente brasileiro. Pode-se dizer que a consecução de um prestação jurisdicional mais célere é um objetivo mundialmente perseguido.

${ }^{20}$ BANCO MUNDIAL (2004, p. 32 - 33).
} 
quão grande é a carga média de trabalho do magistrado brasileiro, que, em geral, é maior do que a encontrada nos demais países.

Estatísticas comparativas sobre as Cargas de Trabalho do Judiciário: ${ }^{21}$

\begin{tabular}{|c|c|c|c|}
\hline País & $\begin{array}{l}\text { Ações ajuizadas (ou } \\
\text { sentenças) por } \\
100.000 \text { habitantes }\end{array}$ & $\begin{array}{l}\text { Juízes por } \\
100.000 \\
\text { habitantes }\end{array}$ & $\begin{array}{c}\text { Ações ajuizadas } \\
\text { (ou sentenças) por } \\
\text { juiz }\end{array}$ \\
\hline Honduras & 1.200 & 8,8 & 136 \\
\hline Venezuela & 2.375 & 6,3 & 377 \\
\hline El Salvador & 2.454 & 11,8 & 208 \\
\hline $\begin{array}{c}\text { México, apenas Distrito } \\
\text { Federal }\end{array}$ & 2.600 & 4,0 & 650 \\
\hline $\begin{array}{l}\text { BRASIL (apenas federais, } \\
\text { trabalhistas e estaduais - } \\
\text { militares, eleitorais e juizados } \\
\text { especiais não incluídos) }\end{array}$ & 7.171 & 5,3 & 1.357 \\
\hline Argentina & 9.459 & 10,9 & 875 \\
\hline Colômbia & 3.298 & 7,7 & 430 \\
\hline Costa Rica & 21.000 & 15,9 & 1.320 \\
\hline Inglaterra e País de Gales & 9.800 (sentenças) & 11 & 891 (sentenças) \\
\hline França & 6.200 (sentenças) & 13 & 477 (sentenças) \\
\hline Itália & 14.000 (sentenças) & 20 & 700 (sentenças) \\
\hline Alemanha & 15.600 (sentenças) & 23 & 678 (sentenças) \\
\hline $\begin{array}{l}\text { EUA, Distrito de Colúmbia } \\
\text { (apenas cíveis) }\end{array}$ & 20.321 & 10,21 & 1.992 \\
\hline EUA, Maine (apenas cíveis) & 2.821 & 1,29 & 2.187 \\
\hline
\end{tabular}

Ao lado da elevadíssima carga de trabalho, há um outro grave problema que diz respeito à má distribuição do volume de trabalho entre os magistrados. Alguns dados atingem cifras verdadeiramente impressionantes.

\footnotetext{
${ }^{21}$ Os dados relativos a Honduras, Venezuela, México, Brasil e Argentina são relativos ao ano de 2002; os concernentes a El Salvador, Colômbia, Costa Rica, Inglaterra e País de Gales, França, Itália e Alemanha se referem a 2001; e, por fim, os que dizem respeito ao Distrito de Colúmbia e Maine (EUA) se referem ao início da década de 1990.
} 
Cada ministro do Supremo Tribunal Federal, por exemplo, já chegou a receber mais de 10.000 (dez mil) processos por ano. Esse quantitativo exorbitante, todavia, vem diminuindo nos últimos anos, graças à adoção de um novo requisito de admissibilidade do recurso extraordinário, a saber: a repercussão geral das questões constitucionais discutidas no caso.

O Superior Tribunal de Justiça, atualmente composto por trinta e três ministros, dos quais apenas trinta funcionam como relatores dos processos distribuídos, no ano de 2007 recebeu a cifra de 313.364 (trezentos e treze mil trezentos e sessenta e quatro) processos. Neste ano, portanto, cada ministro relator recebeu, em média, mais de 10.000 (dez mil) novos processos, isso sem contar a grande quantidade de processos em trâmite no gabinete que aguardam julgamento.

Segundo dados do relatório do Banco Mundial, os juízes dos juizados especiais federais também recebem um grande de número de processos, chegando a proferir 7.000 ou 8.000 (sete ou oito mil) sentenças por ano. ${ }^{22}$

Além da reduzida quantidade de juízes, o número de processos distribuídos vem crescendo de forma significativa nas últimas décadas. De ano a ano ocorrem oscilações na quantidade de processos distribuídos. Na maior parte das vezes, verifica-se um aumento do número de processos submetidos à apreciação do Poder Judiciário. Em outros momentos, contudo, ocorrem reduções, que, por vezes, podem ser justificadas, pela adoção de medidas voltadas para a racionalização da atividade judiciária, de que é exemplo o instituto da repercussão geral.

Entre aumentos e reduções no número de processos distribuídos, há, entretanto, uma clara e pujante tendência de ampliação da demanda pela tutela

\footnotetext{
${ }^{22}$ BANCO MUNDIAL (2004, p. 31).
} 
jurisdicional, o que tem motivado alguns autores a utilizar a expressão "explosão de litigiosidade" para qualificar este fenômeno, que tem como marco inicial a década de $70^{23}$

A fim de ilustrar o grande aumento da carga de trabalho que o Poder Judiciário vem experimentando nos últimos anos - que é uma tendência de caráter geral, que atinge todos os seus ramos - trazemos os dados estatísticos do Supremo Tribunal Federal $^{24}$ e do Superior Tribunal de Justiça ${ }^{25}$ :

\begin{tabular}{|c|c|c|c|c|c|c|c|c|c|c|c|}
\hline Movimentação STF & 1945 & 1950 & 1955 & 1960 & 1965 & 1970 & 1975 & 1980 & 1985 & 1990 & 1995 \\
\hline Proc. Protocolados & 3.422 & 3.091 & 5.015 & 6.504 & 8.456 & 6.367 & 8.775 & 9.555 & 18.206 & 18.564 & 27.743 \\
\hline Proc. Distribuídos & 2.566 & 2.938 & 4.686 & 5.946 & 13.929 & 6.716 & 9.324 & 9.308 & 17.935 & 16.226 & 25.385 \\
\hline Julgamentos & 1.860 & 3.371 & 4.146 & 5.747 & 6.241 & 6.486 & 9.083 & 9.007 & 17.798 & 16.449 & 34.125 \\
\hline Acórdãos publicados & 1.801 & 3.395 & 3.730 & 4.422 & 5.204 & 3.328 & 3.913 & 3.366 & 4.782 & 1.067 & 19.507 \\
\hline
\end{tabular}

\begin{tabular}{|c|l|l|l|l|l|l|l|l|l|l|l|}
\hline Movimentação STF & 2000 & 2001 & 2002 & 2003 & 2004 & 2005 & 2006 & 2007 & 2008 & 2009 & 2010 \\
\hline Proc. Protocolados & 105.307 & 110.771 & 160.453 & 87.186 & 83.667 & 95.212 & 127.535 & 119.324 & 100.781 & 84.369 & 71.670 \\
\hline Proc. Distribuídos & 90.839 & 89.574 & 87.313 & 109.965 & 69.171 & 79.577 & 116.216 & 112.938 & 66.873 & 42.729 & 41.014 \\
\hline Julgamentos & 86.138 & 109.692 & 83.097 & 107.867 & 101.690 & 103.700 & 110.284 & 159.522 & 130.747 & 121.316 & 103.869 \\
\hline Acórdãos publicados & 10.770 & 11.407 & 11.685 & 10.840 & 10.674 & 14.173 & 11.421 & 22.257 & 19.377 & 17.704 & 10.814 \\
\hline
\end{tabular}

\begin{tabular}{|c|c|c|c|c|c|c|c|c|c|c|c|}
\hline Movimentação STJ & 1990 & 1991 & 1992 & 1993 & 1994 & 1995 & 1996 & 1997 & 1998 & 1999 & 2000 \\
\hline Proc. Distribuídos & 14.087 & 23.368 & 33.872 & 33.336 & 38.670 & 68.576 & 77.032 & 96.376 & 92.107 & 118.977 & 150.738 \\
\hline Proc. Julgados & 11.742 & 19.267 & 31.428 & 35.105 & 43.032 & 62.332 & 77.629 & 102.054 & 101.467 & 128.042 & 154.164 \\
\hline
\end{tabular}

\begin{tabular}{|c|c|c|c|c|c|c|c|c|c|c|}
\hline Movimentação STJ & 2001 & $\mathbf{2 0 0 2}$ & $\mathbf{2 0 0 3}$ & $\mathbf{2 0 0 4}$ & $\mathbf{2 0 0 5}$ & $\mathbf{2 0 0 6}$ & $\mathbf{2 0 0 7}$ & $\mathbf{2 0 0 8}$ & $\mathbf{2 0 0 9}$ & $\mathbf{2 0 1 0}$ \\
\hline Proc. Distribuídos & 184.478 & 155.959 & 226.440 & 215.411 & 211.128 & 251.020 & 313.364 & 271.521 & 292.103 & 228.981 \\
\hline Proc. Julgados & 198.613 & 171.980 & 216.999 & 241.309 & 271.428 & 262.343 & 330.257 & 354.042 & 328.718 & 330.283 \\
\hline
\end{tabular}

Muito embora o número de processos julgados também esteja aumentando ao longo dos anos, esta tendência, como é de intuitiva percepção, não pode persistir por muito tempo se não vier acompanhada de uma correlata ampliação do número de magistrados, da estrutura material, de pessoal e

\footnotetext{
${ }^{23}$ FARIA, José Eduardo (2003, p. 6).

${ }^{24}$ Dados disponíveis em: <http://www.stf.jus.br/portal/cms/verTexto.asp?servico=estatistica\&pagina=movimentoProcessual>. Acesso em 09 de junho de 2011.

${ }^{25}$ Dados disponíveis em: <http://www.stj.jus.br/webstj/Processo/Boletim/verpagina.asp?vPag=1\&vSeq=168>. Acesso em 09 de junho de 2011.
} 
tecnológica do Poder Judiciário, assim como do desenvolvimento e utilização de instrumentos processuais idôneos à promoção de uma tutela jurisdicional adequada e mais célere. Produzir cada vez mais julgamentos, contando com os mesmos recursos disponíveis anteriormente, em geral, representa perdas progressivas da qualidade ${ }^{26}$ das decisões judiciais.

Nesta esteira de raciocínio, Aluisio Gonçalves de Castro Mendes adverte que:

\begin{abstract}
A quantidade excessiva de processos distribuídos e julgados acarreta a perda de qualidade nos pronunciamentos judiciais, que não comportam, inobstante o auxílio de funcionários e recursos materiais, produção em escala industrial, tendo em vista a natureza da atividade, que se desenvolve, ou deveria ser realizada, com razoável firmeza e segurança, por meio do exame minucioso dos autos, da análise das provas, dos fatos e do direito. A quantidade excessiva de processos já extrapolou o limite do suportável, pois os juízes são seres humanos e, para o bom desempenho da função, necessitam, além de permanente estudo e aperfeiçoamento, de um mínimo de serenidade e tempo para refletir. ${ }^{27}$
\end{abstract}

Diante desse quadro em que a estrutura do Poder Judiciário é pequena para dar conta de toda a carga de trabalho que lhe é submetida diariamente, agravado pelo contínuo aumento do número de processos distribuídos, o resultado não poderia ser outro que não a demora da prestação jurisdicional.

Augusto Martinez e Luciana Campanelli, aludindo a estatísticas do Banco Nacional de Dados do Poder Judiciário (BNDPJ), apontam o Tribunal de Justiça de São Paulo e o Tribunal Regional Federal da $3^{\mathrm{a}}$ Região como as cortes mais lentas do País, com estimativa temporal para o julgamento de um recurso de apelação (sem prioridade legal ou regimental) para mais de 5 (cinco) anos. ${ }^{28}$

É tão grave o problema da morosidade da justiça que o Código de Processo Civil Brasileiro de 1973 vem sendo constantemente modificado nas últimas décadas.

\footnotetext{
${ }^{26}$ É válida aqui também a observação feita na nota de rodapé de $n^{\circ} 14$.

${ }^{27}$ MENDES, Aluisio Gonçalves de Castro (2008, p. 978).

${ }^{28}$ PEREZ, Augusto Martinez e ROMEU, Luciana Campanelli (jul./set. 2008, p. 25).
} 
A partir do ano de 1994, as reformas do estatuto processual civil brasileiro se intensificaram sobremaneira. Desde esse ano aos dias hodiernos, dezenas de leis foram produzidas com o escopo de promover mais efetividade e celeridade ${ }^{29}$ à tutela jurisdicional. Como afirma Bruno Freire e Silva "a urgência justificou a realização de minirreformas ao invés da criação de um novo Código de Processo Civil, que demandaria muito mais tempo e trabalho." ${ }^{30}$

São tantas as leis reformadoras, que seria absolutamente inviável tratar de todas elas com detalhes no presente trabalho monográfico. ${ }^{31}$ De todo modo, para que possamos nos situar dentro do momento histórico em que vivemos, é de crucial importância extrair das reformas empreendidas as tendências que têm orientado o desenvolvimento do processo civil contemporâneo.

Uma importante alteração do estatuto processual civil brasileiro diz respeito a generalização da antecipação de tutela. Como conseqüência deste fenômeno, o instituto em apreço - que encontrava previsão normativa apenas em alguns procedimentos especiais como, por exemplo, nas ações possessórias - hoje constitui uma providência aplicável em qualquer processo.

Assim, além das medidas cautelares específicas previstas no art. 813 e seguintes do CPC e do poder geral de cautela do magistrado positivado no art. 798 desse diploma legal, os aplicadores da lei, dentro do gênero tutelas de urgência, passaram a contar na atualidade com a tutela antecipada ${ }^{32}$.

Com efeito, a valorização da antecipação de tutela - que proporciona a provisória atribuição do bem da vida à parte, permitindo-lhe desfrutá-lo

\footnotetext{
${ }^{29}$ Como visto, o atributo celeridade integra o conceito de efetividade. Contudo, tem-se preferido explicitá-lo, para deixá-lo em destaque, realçando com isto o seu valor.

${ }^{30}$ SILVA, Bruno Freire e (2008, p. 983).

${ }^{31}$ Para uma visa geral, sobre cada uma das leis que integram o movimento de reforma do Código de Processo Civil, confira-se o artigo de Fernanda Medina Pantoja, intitulado "Reformas processuais: sistematização e perspectivas". In: Revista de processo, v. 33, n. 160, p. 87-114, jun. 2008

${ }^{32}$ SILVA, Bruno Freire e (2008, p. 983).
} 
juridicamente, tal como se a lide já tivesse sido solucionada em seu favor ${ }^{33}$ - está bem afinada com a busca da efetividade do processo.

Por vezes, o titular de um direito necessita de uma providência jurisdicional urgente, não podendo aguardar o curso normal do processo sem assumir um grave risco de lesão ou perecimento do seu direito. Nesses casos, o processamento regular do processo daria grande ensejo à ineficácia do provimento jurisdicional. Fica fácil perceber, então, quão grande é a importância da antecipação de tutela; negar aplicabilidade a esse instituto importaria em vedar o acesso à justiça daqueles que precisam do amparo do Estado-juiz em caráter emergencial.

A Lei 8.952 de 13 de dezembro de 1994, que deu nova redação ao artigo 273 do Código de Processo Civil, foi a responsável pela previsão em caráter geral da antecipação de tutela. Posteriormente, ao acrescentar o $\S 6^{\circ}$ ao artigo 273 do CPC, a Lei 10.444/02 ampliou ainda mais as hipóteses de aplicação do instituto: permite-se, agora, a concessão de tutela antecipada, quando um ou mais dos pedidos cumulados, ou parcela deles, mostrar-se incontroverso.

Ao lado do alargamento das tutelas de urgência, o direito processual vem seguindo um movimento de afastamento do formalismo vazio, que mais burocratiza do que coopera com o exercício da atividade jurisdicional. Assim, o legislador, buscando promover a simplificação de procedimentos e prestigiando o princípio da economia processual, dentre outras alterações: (a) passou a dispensar o reconhecimento de firma na procuração outorgada ao advogado (artigo 38, caput, do CPC, com a redação determinada pela Lei 8.952/1994); (b) outorgou a este poderes para declarar, para fins processuais, a autenticidade de cópias reprográficas de peças do processo (inciso IV do art. 365, alterado pela Lei 11.382/2006); (c) 
simplificou o procedimento de produção da prova pericial através da Lei 8.455/1992; (d) retirou do reexame necessário as causas com valor de até 60 (sessenta) salários mínimos e a sentença que decreta a anulação do casamento, preservando as demais hipóteses do instituto previstas no art. 475 do CPC; (e) aumentou o teto para utilização do rito sumário (art. 275, I, com a redação conferida pela Lei 10.444/2002); (f) deu passos decisivos em direção à unificação da teoria das medidas urgentes, prevendo a fungibilidade entre as providências antecipatórias e as medidas cautelares, nos termos do art. 273, § $7^{\circ}$ do CPC, acrescentado pela Lei 10.444; (g) promoveu a unificação entre a atividade cognitiva e a executiva, que agora constituem fases de uma mesma relação jurídica processual; (h) alterou a natureza jurídica da liquidação de sentença que deixou de ser uma ação incidental e passou a figurar como procedimento incidental, disciplinado nos art. 475-A a $475-\mathrm{H}$, adicionados ao CPC, por força da Lei 11.232/2005; (i) autorizou o tribunal a julgar de pronto a lide quando a parte interpuser apelação contra sentença de extinção do processo sem julgamento do mérito, e a causa versar questão exclusivamente de direito e estiver em condições de imediato julgamento, conforme dispõe o $\S 3^{\circ}$ do art. 515, com a redação estabelecida pela Lei 10.352/2001; (j) permitiu, em caso de nulidade sanável, a realização ou renovação do ato processual em segundo grau, sem a necessidade de os autos retornarem à origem (art. 515, § $4^{\circ}$ do CPC, acrescentado pela Lei 11.276/2006).

Outrossim, o legislador tem dedicado esforços para a criação e adoção de instrumentos e recursos mais adequados a realização dos atos processuais, assim como de vias alternativas de resolução das controvérsias. Foi com estes ideais que (a) priorizou a citação pelo correio, que, como se sabe, é mais célere e de custo menor que a realizada por oficial de justiça (art. 222 com a redação dada pela Lei 
8.710/1993); (b) permitiu que o juiz, a requerimento do exeqüente, requisite à autoridade supervisora do sistema bancário, informações sobre a existência de ativos financeiros em nome do executado, podendo no mesmo ato determinar sua indisponibilidade, até o valor da execução (art. 655-A acrescentado pela Lei 11.382/2006); (c) permitiu, a requerimento do exeqüente, a realização de alienação em hasta pública por meio da rede mundial de computadores, com uso de páginas virtuais criadas pelos Tribunais ou por entidades públicas ou privadas em convênio com eles firmado (art. 689-A, adicionado pela Lei 11.382/2006); (d) autorizou o devedor a promover a consignação em pagamento por via extrajudicial, através do sistema bancário, com maior agilidade e menores custos ( $\S \S 1^{\circ}$ ao $4^{\circ}$ acrescidos ao art. 890 do CPC, por meio da Lei 8.951/1994); (e) criou a arbitragem por intermédio da Lei 9.307/1996, instituto que confere às pessoas capazes de contratar a faculdade de dirimir litígios relativos a direitos patrimoniais disponíveis ${ }^{34}$; (f) possibilitou a realização de inventário, partilha, separação e divórcio consensuais por escritura pública, desde que não haja interesse de menores ou incapazes e as partes envolvidas estejam assistidas por advogado ou defensor público.

Nessa busca pela consecução da efetividade da tutela jurisdicional o direito processual tem dado passos rumo à informatização do processo judicial. Embora a adaptação do processo brasileiro à utilização dos meios eletrônicos esteja ocorrendo pouco a pouco, em termos normativos já se vê um grande avanço, especialmente com a promulgação da Lei 11.419/2006, que preparou terreno para a informatização do processo. Entre inúmeras disposições normativas, é de especial destaque o acréscimo do $\S 2^{\circ}$ ao art. 154, assim redigido: “§ $2^{\circ}$ Todos os atos e

\footnotetext{
${ }^{34}$ A arbitragem, meio alternativo de resolução de conflitos, substituiu o antigo juízo arbitral, disciplinado pelos revogados artigos 1.072 a 1.102 do CPC. Enquanto na sistemática anterior, o laudo arbitral dependia da homologação judicial para ter eficácia de sentença, hoje, faculta-se aos árbitros a produção de sentença arbitral, que não se sujeita a recurso ou a homologação pelo Poder Judiciário e, sendo condenatória, constitui título executivo judicial. Confira-se a propósito os artigos 18 e 31 da Lei 9.307/1996.
} 
termos do processo podem ser produzidos, transmitidos, armazenados e assinados por meio eletrônico, na forma da lei".

Outra nítida tendência do processo é o fortalecimento dos poderes dos magistrados, a crescente valorização da jurisprudência como fonte do direito e a limitação de acesso à jurisdição exercida pelo Supremo Tribunal Federal e pelo Superior Tribunal de Justiça (fruto das alterações legislativas promovidas no recurso extraordinário e no recurso especial).

Dentro desse contexto, o legislador brasileiro conferiu poderes ao juiz do $1^{\circ}$ grau de jurisdição (a) para limitar o litisconsórcio facultativo quanto ao número de litigantes, quando este comprometer a rápida solução do litígio ou dificultar a defesa (art. 46, parágrafo único, acrescentado pela Lei 8.952/1994); (b) para reformar a decisão de indeferimento da inicial, no prazo de 48 horas, caso o autor apele (art. 296, caput, com a redação determinada pela Lei 8952/1994); (c) para aplicar, de ofício ou a requerimento da parte, pena de multa ao litigante de má-fé (art. 18, com as alterações promovidas pelas Leis 8.952/1994 e 9.668/1998); (d) para declarar de ofício a prescrição (art. 219, § 5, com a redação estabelecida pela Lei 11.280/2006); (e) para não receber o recurso de apelação quando a sentença que tiver proferido estiver em conformidade com súmula do Superior Tribunal de Justiça ou do Supremo Tribunal Federal (art. 518, § 1º, acrescentado pela Lei 11.276/2006).

Outrossim, o legislador conferiu ao relator poderes (a) para decidir conflito de competência de plano, quando houver jurisprudência dominante sobre a matéria objeto de apreciação (art. 120, parágrafo único, adicionado pela Lei 9.756/1998); (b) para negar seguimento a recurso manifestamente inadmissível, improcedente, prejudicado ou em confronto com súmula ou com jurisprudência dominante do respectivo tribunal, do Supremo Tribunal Federal ou de Tribunal Superior (art. 557, 
caput); (c) para dar provimento, monocraticamente, a recurso quando a decisão recorrida estiver em manifesto confronto com súmula ou com jurisprudência dominante do Supremo Tribunal Federal, ou de Tribunal Superior (art. 557, § 1º-A); (d) para negar seguimento a agravo de instrumento nas mesmas hipóteses do caput do art. 557 (acima mencionadas), para convertê-lo em agravo retido, atribuir-lhe efeito suspensivo ou, ainda, deferir, em antecipação de tutela, total ou parcialmente, a pretensão recursal, comunicando ao juiz sua decisão (art. 527, I, II e III).

Também merecem destaque como medidas que prestigiam a jurisprudência: (a) o acréscimo do $\S 3^{\circ}$ ao artigo 475 do CPC pela Lei 10.352/2001, por meio do qual o reexame necessário das causas previstas nos incisos I e II do art. 475 restou afastado, quando a sentença prolatada estiver fundada em jurisprudência do plenário do Supremo Tribunal Federal, ou em súmula do STF ou do tribunal superior competente; (b) a criação da súmula vinculante por meio da EC no 45 e, posteriormente, a regulamentação do procedimento para sua edição, cancelamento e revisão através da Lei 11.417/2006.

Nos termos do art. 103-A, caput e $\S 3^{\circ}$, a súmula vinculante é instituto que, a partir de sua publicação na imprensa oficial, tem efeito vinculante em relação aos demais órgãos do Poder Judiciário e à administração pública direta e indireta, nas esferas federal, estadual e municipal, cabendo do ato administrativo ou decisão judicial que contrariar a súmula aplicável ou que indevidamente a aplicar reclamação ao Supremo Tribunal Federal que, julgando-a procedente, anulará 0 ato administrativo ou cassará a decisão judicial reclamada, e determinará que outra seja proferida com ou sem a aplicação da súmula. 
A limitação do acesso ao STF e ao STJ, certamente, mais cedo ou mais haveria de ocorrer, como efetivamente ocorreu, dado o constante e intenso aumento do número de processos distribuídos.

Dentro deste cenário tão desfavorável, a EC no 45 criou o instituto da repercussão geral, posteriormente regulado pela Lei 11.418/2006, que acresceu ao Código de Processo Civil os artigos 543-A e 543-B. A repercussão geral das questões constitucionais discutidas consiste em novo requisito de admissibilidade do recurso extraordinário, devendo o recorrente demonstrar que as matérias submetidas à apreciação da Suprema Corte são de tal modo relevantes do ponto de vista econômico, político, social ou jurídico, que ultrapassam os interesses subjetivos da causa e merecem apreciação pelo Supremo Tribunal Federal.

Cabe ao STF decidir a existência ou inexistência da repercussão geral e, estando preenchidos os demais pressupostos de admissibilidade do recurso extraordinário, passar ao julgamento do mérito. Com o fito de tornar o instrumento ainda mais efetivo, o legislador determinou o sobrestamento pelo Tribunal de origem dos recursos extraordinários repetitivos e conferiu à decisão do STF que apreciar a existência da repercussão geral e à decisão final de mérito dos RE's efeito vinculante, nos termos do disposto nos artigos 543-A, $\S 5^{\circ}$ e 543-B, $\S \S 2^{\circ}, 3^{\circ}$ e $4^{\circ}$.

Com todo esse regramento, tem-se falado no surgimento de um fenômeno denominado "objetivação do recurso extraordinário". Como alude Ulisses Schwarz Viana, "o Supremo Tribunal Federal deixará de julgar processos (casos inter partes) e, objetivamente, julgará questões constitucionais, ou seja, temas constitucionais com repercussão econômica, política, social e jurídica”35. 
O processamento do recurso especial sofreu as alterações ditadas pela Lei 11.672/2008, que, acrescentando o artigo 543-C ao estatuto processual, disciplinou o procedimento para o julgamento de recursos especiais repetitivos com fundamento em idêntica questão de direito, no âmbito do Superior Tribunal de Justiça.

Nos termos do $\S 1^{\circ}$ do aludido dispositivo, caberá ao presidente do tribunal de origem admitir um ou mais recursos representativos da controvérsia e encaminhá-los ao STJ, sobrestando os demais que permanecerão suspensos até pronunciamento definitivo da Corte Superior. O julgamento final dos recursos especiais representativos da controvérsia terá efeito vinculante sobre os que restaram sobrestados, conforme se pode verificar no $\S 7^{\circ}$ do art. 543-C.

Com tal sistemática, o legislador pretende reduzir o número de recursos a serem submetidos à apreciação do Superior Tribunal de Justiça, conferindo também maior racionalidade ao procedimento de julgamento de recursos especiais interpostos com fundamento na mesma questão de direito.

Com efeito, à luz das transformações mencionadas, sobretudo daquelas voltadas à valorização da jurisprudência como fonte do direito, pode-se dizer, sem exageros, que o processo civil brasileiro, cujos institutos derivam do sistema romano-germânio (civil law), vem experimentando um momento histórico ímpar de aproximação do direito anglo-saxão (common law), no que diz respeito ao fortalecimento do precedente judicial.

Por fim, cumpre destacar a mais importante tendência do direito processual contemporâneo, que diz respeito à instrumentalização do processo. A nosso sentir, o direito processual não poderia seguir caminho diverso. Como se sabe, o processo é o meio de que se vale o Estado para prestar a jurisdição. Em 
outras palavras, a função do processo - ressalvada a hipótese do exercício da jurisdição voluntária, na qual não há conflito - é ensejar a composição da lide, dando ao titular da posição jurídica de vantagem o bem da vida vindicado; o processo foi criado precisamente para isto.

À medida que o processo deixa de ser visto como meio e passa a ser encarado como um fim em si mesmo, tanto mais perde o caráter instrumental, que Ihe confere utilidade e justifica a sua própria existência.

Instrumentalismo e efetividade, como assevera Humberto Theodoro Júnior, são idéias que se completam na formação do ideário do processualismo moderno. Para ser efetivo no alcance das metas de direito substancial, o processo tem de assumir plenamente sua função de instrumento. ${ }^{36}$

O atributo "instrumentalidade" é tão inerente ao conceito de efetividade que toda medida que promove o aumento da efetividade da tutela jurisdicional coloca o direito processual a serviço do direito material, ou seja, faz do processo um instrumento mais adequado à concretização da vontade da lei substancial.

Desse modo, todas as tendências anteriormente destacadas, que têm por finalidade comum a promoção da efetividade do processo civil contemporâneo, são também medidas promotoras da instrumentalização do direito adjetivo. Pode-se dizer, portanto, que a tendência ora em apreço engloba todas as outras acima mencionadas.

Dentre as inúmeras alterações do estatuto processual civil, uma delas, que vem em nome da economia processual e da racionalização do sistema com a conseqüente promoção de celeridade ao provimento jurisdicional, tem gerado dúvidas acerca de sua constitucionalidade e será objeto de análise desta pesquisa.

\footnotetext{
${ }^{36}$ THEODORO JÚNIOR, Humberto (2009, p. 16).
} 
Consiste no acréscimo do artigo 285-A ao Código de Processo Civil, que confere ao magistrado poderes para, atendidos os requisitos estabelecidos no dispositivo legal, dispensar a citação do réu e proferir sentença de total improcedência dos pedidos do autor. 


\section{4. $O$ artigo 285-A do Código de Processo Civil e o debate acerca da sua constitucionalidade.}

A Lei 11.277 , de 7 de fevereiro de 2006, publicada no dia seguinte, acrescentou o artigo 285-A ao Código de Processo Civil. A fim de propiciar um exame mais detido sobre a alteração promovida no estatuto processual, transcrevese abaixo a íntegra da referida $l e^{37}$ :

Lei $n^{\circ}$ 11.277, de 7 de Fevereiro de 2006

Acresce o art. 285-A à Lei $n^{0}$ 5.869, de 11 de janeiro de 1973, que institui o Código de Processo Civil.

O PRESIDENTE DA REPÚBLICA Lei:

Faço saber que o Congresso Nacional decreta e eu sanciono a seguinte

Art. $1^{\circ}$ Esta Lei acresce o art. 285-A à Lei $n^{\circ} 5.869$, de 11 de janeiro de 1973, que institui o Código de Processo Civil.

Art. $2^{\circ}$ A Lei $n^{\circ} 5.869$, de 11 de janeiro de 1973, que institui o Código de Processo Civil, passa a vigorar acrescida do seguinte art. 285-A:

"Art. 285-A. Quando a matéria controvertida for unicamente de direito e no juízo já houver sido proferida sentença de total improcedência em outros casos idênticos, poderá ser dispensada a citação e proferida sentença, reproduzindo-se o teor da anteriormente prolatada.

$\S 1^{\circ}$ Se o autor apelar, é facultado ao juiz decidir, no prazo de 5 (cinco) dias, não manter a sentença e determinar o prosseguimento da ação.

$\S 2^{\circ}$ Caso seja mantida a sentença, será ordenada a citação do réu para responder ao recurso."

Art. $3^{\circ}$ Esta Lei entra em vigor 90 (noventa) dias após a data de sua publicação.

Brasília, 7 de fevereiro de 2006; $185^{\circ}$ da Independência e $118^{\circ}$ da República.

LUIZ INÁCIO LULA DA SILVA

Márcio Thomaz Bastos

Publicação:

Diário Oficial da União - Seção 1 - 08/02/2006, Página 2 (Publicação Original)

Segundo o caput do artigo 285-A, o juiz - ao verificar que a matéria submetida a sua apreciação é unicamente de direito e que no juízo já foi proferida sentença de total improcedência em outros casos idênticos - poderá dispensar a

\footnotetext{
37 Disponível em: <http://www2.camara.gov.br/legin/fed/lei/2006/lei-11277-7-fevereiro-2006-540955-publicacaooriginal-42497pl.html>. Acesso em 10 de junho de 2011.
} 
citação do réu e reproduzir a sentença anteriormente prolatada. Trata-se de uma hipótese de indeferimento liminar da petição inicial. Em outras palavras, o magistrado julga a causa prima facie, com a tão-só análise da exordial.

Cumpre esclarecer, desde logo, que o julgamento liminar (ou imediato) da ação, já existia no ordenamento jurídico brasileiro, antes da alteração promovida pela Lei 11.277/2006. Em todas as hipóteses de indeferimento da petição inicial (que estão previstas nos incisos do caput e do parágrafo único do artigo 295 do Código de Processo Civil), o juiz pode sentenciar o processo sem determinar a citação do réu.

De um modo geral, o indeferimento da petição inicial previsto no art. 295 do CPC conduz à extinção do processo sem resolução do mérito, como revela o artigo 267, I, do CPC. Entretanto, nas hipóteses do inciso IV do caput daquele dispositivo (reconhecimento de ofício da decadência e da prescrição), a sentença proferida em caráter liminar, a teor do disposto no art. 269, IV, resolverá o mérito da causa.

A Lei 11.277 criou mais uma possibilidade de julgamento liminar com resolução do mérito. Na hipótese do artigo 285-A do CPC, o magistrado haverá de concluir pela improcedência dos pedidos, já que a sentença paradigma é de improcedência. Desse modo, o provimento jurisdicional necessariamente será de mérito, a teor do que dispõe o art. 269, I do estatuto processual e, transitando em julgado, adquirirá status de coisa julgada material entre as partes.

Com efeito, o legislador procurou prestigiar o princípio da economia processual e conferir, em conseqüência, maior racionalidade e celeridade à atividade jurisdicional. É possível que chegue a uma mesma vara centenas de casos idênticos sobre os quais a matéria seja exclusivamente de direito, e em face dos 
quais o juízo já tenha entendimento definido. Sendo o resultado final (improcedência total dos pedidos) conhecido de antemão pelo magistrado, haveria mesmo a necessidade de se realizar tantas citações e dar oportunidade ao oferecimento de tantas contestações e réplicas, para só então o juiz decidir a lide?

Visto por este ângulo, o dispositivo em apreço parece bastante razoável e bem afinado ao propósito de combater a morosidade do Poder Judiciário. Ademais, como apontam José Antonio Fichtner e André Luís Monteiro, "é absolutamente razoável que, diante de questões idênticas, o Estado, ao prestar a tutela jurisdicional, apresente às partes a mesma resposta, resolvendo os litígios com a mesma identidade que os caracteriza, de maneira a garantir, a um só tempo, o princípio da celeridade e o princípio da isonomia” ${ }^{38}$.

Além dos ganhos em celeridade e da observância do princípio da isonomia, Luis Guilherme Aidar Bondioli identifica no dispositivo, na hipótese de a sentença liminar de improcedência transitar livremente em julgado, grandes benefícios para o requerido, que seria poupado dos custos materiais e morais de um processo judicial: o réu terá seus direitos e interesses resguardados por inteiro, sem a necessidade de contratar serviços advocatícios, sem desembolsar valores que demandariam considerável esforço para seu reembolso, nem sempre integral; sem ter que passar pela sempre desgastante experiência de participar de um processo judicial. $^{39}$

Entretanto, a despeito desses inequívocos benefícios e da legítima preocupação do legislador em conferir maior efetividade à prestação jurisdicional, a Lei 11.277, de há muito, tem provocado grandes discussões acerca da sua constitucionalidade.

\footnotetext{
${ }^{38}$ FICHTNER, José Antonio e MONTEIRO, André Luís (jul. 2009, p. 49).

${ }^{39}$ BONDIOLI, Luis Guilherme Aidar (2008, p. 1323).
} 
As normas constitucionais e, sobretudo os princípios constitucionais exercem papel de destaque no ordenamento jurídico. Tal compreensão vem muito bem expressa na definição de Constituição proposta por Konrad Hesse e reproduzida por Gilmar Ferreira Mendes, segundo a qual a Constituição deve ser entendida como a "ordem jurídica fundamental de uma comunidade ou o plano estrutural para a conformação jurídica de uma comunidade, segundo certos princípios fundamentais" 40 .

Adota-se, na presente monografia, com o intuito de realçar a importância dos princípios constitucionais, o modelo teórico proposto por Ronald Dworkin ${ }^{41}$, segundo o qual as normas jurídicas constituem gênero formado por duas espécies: as regras e os princípios.

Em breve síntese, as regras são dotadas de um menor grau de abstração que os princípios; imputam conseqüências jurídicas a determinados fatos previstos abstratamente pelo legislador; operam por meio da subsunção, segundo a lógica do tudo ou nada (ou são aplicáveis ou não o são); "contêm fixações normativas definitivas, sendo insustentável a validade simultânea de regras contraditórias" ${ }^{42}$.

Os princípios, por sua vez, apresentam um grau elevado de abstração; se aplicam a um sem-número de situações, exigindo atuações concretizadoras por parte do legislador e do juiz; constituem mandamentos de otimização, em virtude do que a eles deve ser conferido o máximo grau de concretização, quando de sua incidência; podem conflitar entre si e disso não resultará a exclusão de um pelo outro; coexistem mutuamente e devem ser harmonizados entre si; em eventual conflito, encontram limites uns nos outros, e, apenas por um juízo de ponderação

\footnotetext{
${ }^{40}$ MENDES, Gilmar Ferreira; COELHO, Inocêncio Mártires; e BRANCO, Paulo Gustavo Gonet (2008, p. 11).

${ }^{41}$ Confira-se, a propósito, a obra: "DWORKIN, Ronald. Levando os direitos a sério. Tradução: Nelson Boeira. São Paulo: Martins Fontes, 2010."

${ }^{42}$ CANOTILHO, José Joaquim Gomes. Direito constitucional e teoria da constituição. Coimbra: Almedina, 2002, p. 1148.
} 
que assegure o respeito aos núcleos essenciais de cada um dos princípios conflitantes, um determinado princípio poderá prevalecer sobre outro; constituem elementos fundamentais e estruturantes do sistema jurídico, sobre os quais as regras apóiam-se para existir.

Percebe-se, assim, quão grande é a importância dos princípios e maior ainda será a dos princípios constitucionais, os quais irradiam efeitos sobre todo o ordenamento jurídico, condicionam sua interpretação e autorizam o controle de constitucionalidade das normas infraconstitucionais.

A propósito, Luís Roberto Barroso leciona que os princípios constitucionais são a síntese dos valores abrigados no ordenamento jurídico e espelham a ideologia da sociedade, seus postulados básicos, seus fins. ${ }^{43}$

Toda e qualquer lei deve passar pelo crivo da Constituição Federal. Essa nota é de excepcional importância para as leis que promovem alterações no Código de Processo Civil, haja vista que os grandes princípios conformadores do direito processual estão consagrados na Carta Magna.

Em relação à Lei 11.277 , as principais críticas atinentes a sua constitucionalidade - que serão expostas a seguir - dizem respeito à violação do direito de ação, dos princípios do contraditório, da ampla defesa e, como não poderia deixar de ser, do devido processo legal, que constitui causa de todos os outros princípios constitucionais do processo ${ }^{44}$.

Segundo a redação do caput do artigo 285-A, a prolação da sentença liminar de improcedência, só pode ocorrer quando presentes dois requisitos, a

\footnotetext{
${ }^{43}$ BARROSO, Luís Roberto (2008, p. 29).

${ }^{44}$ Como bem observa Alexandre Freitas Câmara (2009, p. 33), todos os demais princípios constitucionais do Direito Processual são corolários do princípio do devido processo legal. Desse modo, a violação de qualquer um deles necessariamente pressupõe a violação desse último.
} 
saber: (a) que a matéria controvertida seja unicamente de direito; e (b) que haja sido proferida no juízo sentença de total improcedência em casos idênticos.

Quanto ao primeiro requisito, importa esclarecer que, em todo processo judicial, o autor apresenta ao magistrado um determinado contexto fático a partir do qual pede ao Estado-juiz, fundamentando a sua pretensão no ordenamento jurídico, a tutela jurisdicional cabível na espécie.

No processo pode ocorrer controvérsia sobre fatos (quando as partes dão versões diferentes para os fatos ocorridos) e controvérsia sobre direito (quando a divergência diz respeito à interpretação e aplicação das regras jurídicas). Ao juiz cabe, em primeiro lugar, fixar o quadro fático para depois averiguar se o ordenamento jurídico garante a tutela requerida ou não.

Embora todo processo tenha por base um contexto fático, pode ser que as partes sejam concordes quanto aos fatos ocorridos, divergindo apenas quanto à solução jurídica adequada à espécie. Nesses casos, diz-se que a matéria dos autos é unicamente de direito.

Do ponto de vista da precisão técnico-conceitual, a redação dada ao caput do art. 285-A do CPC não fica imune a graves críticas. Segundo o artigo, "quando a matéria controvertida for unicamente de direito e no juízo já houver sido proferida sentença de total improcedência em outros casos idênticos poderá ser dispensada a citação e proferida sentença, reproduzindo-se o teor da anteriormente prolatada". Ora, como o juiz dispensará a citação e proferirá sentença prima facie, não haverá matéria controvertida nos autos, porquanto o réu não foi citado para integrar a relação jurídica processual, quando teria a oportunidade de dar outra versão sobre os fatos ocorridos e apresentar solução jurídica diversa. 
Por isso, a expressão "quando a matéria controvertida for unicamente de direito" é inapropriada, porque não há controvérsia (nem sobre os fatos e nem sobre o direito aplicável ao caso). Sem dúvida, mais correto é ler essa expressão da seguinte forma: "quando a matéria for unicamente de direito". Nesse ponto, surge outra perplexidade: o réu, ao apresentar resposta à petição inicial, sempre pode dar nova versão sobre o contexto fático narrado pelo autor e trazer ao processo os fundamentos jurídicos que entende pertinentes para afastar a pretensão do requerente. Como o juiz poderia, então, saber que a matéria é unicamente de direito antes da citação do réu? Não seria necessário promover primeiro sua citação para que o juiz pudesse concluir qual é a matéria controvertida no caso (se de fato, de direito ou se de fato e de direito)?

Sem dúvida, esse é o primeiro problema do artigo, que, necessariamente, reclama uma solução, sob pena de tornar a alteração promovida pela Lei 11.277 letra morta. Ora, se o juiz tiver que esperar a resposta do réu para concluir que a matéria é unicamente de direito o dispositivo perderá aplicabilidade.

De fato, o magistrado com a tão-só análise da petição inicial jamais poderá afirmar, com 100\% (cem por cento) de certeza, que a matéria dos autos é unicamente de direito. Todavia, o ordenamento jurídico, nem sempre exige certeza absoluta para justificar uma determinada providência jurisdicional. Isso ocorre, por exemplo, com a antecipação de tutela pela qual o magistrado, em juízo de verossimilhança (vale dizer, sem a cognição exauriente da matéria), pode dar à parte, provisoriamente, o bem da vida pleiteado.

Da mesma forma sucederá com a aplicação do artigo 285-A. O juiz deve valer-se do dispositivo em exame, quando houver, no caso, segurança grande o 
suficiente de que não haverá controvérsia sobre fatos, a ponto de justificar a incidência do artigo.

Suponha-se, como exemplo, que o indivíduo "A" proponha ação contra o Município "B", alegando a inconstitucionalidade de um tributo municipal recém-criado e requerendo, por este motivo, seja declarada a inexigibilidade do pagamento. Tratase de uma hipótese em que é absolutamente improvável o surgimento de discussões acerca de matéria fático-probatória, de sorte que o magistrado poderia considerar como cumprido o primeiro requisito de que trata o artigo em exame.

Em caso de dúvida, o magistrado não poderá aplicar o artigo 285-A. Deverá, sim, ordenar a citação do réu, permitindo que ele participe adequadamente do processo, apresentando resposta e produzindo, se o caso, as provas que entender necessárias a sua defesa.

A propósito confira-se a seguinte decisão do Tribunal Regional Federal da 1ª Região:

PROCESSUAL CIVIL. ADMINISTRATIVO. AÇÃO DE DESCONSTITUIÇÃO DE TÍTULO. CANCELAMENTO DE REGISTRO IMOBILIÁRIO. AUSÊNCIA DE CITAÇÃO. NULIDADE.

1. Para a validade de uma relação processual, faz-se necessária a existência de citação válida da parte ré.

2. A ausência de citação vicia o processo, atingindo-o na sua validade, a teor do art. 214, caput, do Código de Processo Civil, razão pela qual se impõe deva ser reconhecida a nulidade do processo, a partir do momento em que deveria ter ocorrido a citação, e ela não se deu, por afronta aos princípios constitucionais da ampla defesa, do contraditório e do devido processo legal.

3. Não se pode falar in casu no julgamento imediato do processo, na forma do art. 285-A, do Código de Processo Civil, pois o referido dispositivo legal autoriza a dispensa de citação e a prolação da sentença de plano, quando se tratar de questão unicamente de direito, o que, na hipótese ora em comento, não se pode com segurança afirmar. (grifo nosso)

4. Nulidade do processo, a partir do momento em que deveria ter ocorrido a citação dos réus. Apelações prejudicadas. ${ }^{45}$

No tocante ao segundo requisito - existência no juízo de sentença de total improcedência em outros casos idênticos ${ }^{46}$-, a aplicação escorreita do artigo exigirá

\footnotetext{
${ }^{45}$ Tribunal Regional Federal da 1a Região: AC 2006.41.00.003173-2/RO, Rel. Desembargador Federal Ítalo Fioravanti Sabo Mendes, Conv. Juíza Federal Rosimayre Gonçalves De Carvalho (conv.), Quarta Turma,DJ p.36 de 12/12/2007.
} 
do magistrado compreensão adequada do que se deva entender pela expressão "casos idênticos". Como bem destacam José Antonio Fichtner e André Luís Monteiro, "a relevância do significado dessa expressão está assentada no fato de que é com base nas sentenças proferidas nesses casos idênticos que se formarão os precedentes do mesmo juízo a serem aplicados nas demandas futuras" ${ }^{47}$.

Procurando, no Código de Processo Civil, elementos que permitam compreender o que sejam "casos idênticos", é possível encontrar no parágrafo $2^{\circ}$ do artigo 301, o conceito de ações idênticas, que nos será muito útil e que transcrevemos aqui: "§ $2^{\circ}$ Uma ação é idêntica à outra quando tem as mesmas partes, a mesma causa de pedir e o mesmo pedido."

É bem verdade que a expressão "casos idênticos" não pode ser encarada como sinônima de "ações idênticas". Isso porque o juiz, ao se deparar com ação idêntica a outra anteriormente proposta, deve extinguir o processo sem julgamento do mérito ex vi dos artigos 301, $\S \S 1^{\circ}$ e $3^{\circ}$ e $267, V$ do CPC. Evidentemente, esta não é a hipótese de cuida o artigo 285-A, cujo resultado final é uma sentença de total improcedência dos pedidos, capaz, portanto, de resolver o mérito da lide.

A Lei 11.277 foi criada com o escopo de racionalizar o processamento das causas repetitivas, ou seja, parte da idéia de que uma sentença proferida em casos paradigmáticos com a observância do procedimento normal previsto possa ser reproduzida noutro processo que trate da mesma matéria e envolva partes diferentes (com o fito de abreviar o procedimento e declarar de imediato o resultado do julgamento, de antemão conhecido).

\footnotetext{
${ }^{46}$ A rigor, por força da expressão "casos idênticos" (no plural), o juiz somente poderá aplicar o artigo 285-A, quando houver pelo menos dois precedentes no juízo.

${ }^{47}$ FICHTNER, José Antonio e MONTEIRO, André Luís (jul. 2009, p. 53).
} 
Assim, o conceito "casos idênticos" difere do conceito "ações idênticas", porque qualifica justamente aquelas ações em que há diversidade de partes. De todo modo, os outros dois elementos presentes no $\S 2^{\circ}$ do artigo 301 (identidade de causas de pedir e de pedidos) devem ser mantidos com rigor.

Importa evidenciar aqui, em relação à causa de pedir, que ela abrange tanto os fatos como os fundamentos jurídicos do pedido, tal qual a redação dada ao inciso III do artigo 282 do CPC. Desse modo, não apenas o contexto fático que o autor invoca para embasar sua pretensão deve ser idêntico ao apresentado nos precedentes do juízo, mas também a fundamentação jurídica.

A esse respeito, José Miguel Garcia Medina, Luiz Rodrigues Wambier e Teresa Arruda Alvim Wambier advertem que "a sentença proferida em ação anterior não poderá ser aproveitada, para os fins do art. 285-A, se na ação subseqüente houver fundamentos novos, sobre os quais deverá manifestar-se o juiz, sob pena de vir a proferir uma sentença omissa"48.

Antes de proceder ao julgamento imediato da causa, previsto no artigo 285-A, o juiz deve verificar se a sentença prolatada nos precedentes do juízo: a) foi proferida para um caso cujo quadro fático é o mesmo da nova ação; b) se ela é capaz de afastar todos os fundamentos jurídicos lançados pelo autor no novo processo e (c) resolver o mérito com a improcedência de todos pedidos. Se tudo isso se verificar, o magistrado estará diante de um caso idêntico aos julgados anteriormente e, sendo a matéria unicamente de direito, poderá proferir sentença prima facie.

Por outro lado, ao menor sinal de que um desses elementos não esteja satisfatoriamente preenchido, o juiz deverá agir com prudência e determinar o

\footnotetext{
${ }^{48}$ MEDINA, José Miguel Garcia; WAMBIER, Luiz Rodrigues; WAMBIER, Teresa Arruda Alvim (2006, p. 69).
} 
processamento regular do feito, determinando a citação do réu. Nesse sentido, Luis Guilherme Aidar Bondioli assevera que "a presença de qualquer peculiaridade na demanda pendente de julgamento ou naquelas já examinadas põe por terra a idéia de casos idênticos e não autoriza a prolação de sentença liminar (p. ex. na demanda por julgar o autor é protegido pelas regras do Código de Defesa do Consumidor e nos outros casos não)". 49

É bem verdade que o texto legal não enumera as hipóteses nas quais seria cabível a aplicação do artigo 285-A. Esta circunstância tem levado a doutrina a dedicar esforços nesta atividade. Para Fredie Didier Jr., por exemplo, o dispositivo deve ter incidência, sobretudo, nos litígios de massa, como as causas previdenciárias, as tributárias, as que envolvem servidores públicos, consumidores ou outros agrupamentos humanos. ${ }^{50}$

Ainda que rigorosamente cumpridos os requisitos legais, o artigo 285-A recebe muitas críticas no tocante a sua constitucionalidade.

A primeira grande crítica dirigida ao artigo 285-A diz respeito à própria possibilidade de o juiz proferir uma sentença prima facie. Com efeito, ao tomar esta providência, o magistrado profere julgamento de imediato, ou seja, logo na primeira oportunidade que tem para se manifestar no processo, quando a relação jurídica processual vincula apenas dois dos três sujeitos processuais, quais sejam: autor e juiz. Para alguns doutrinadores, esta faculdade conferida ao magistrado constitui mecanismo para negar ao autor o regular processamento da causa, que se daria com a citação, ato processual apto a integrar o réu ao processo. Em outras palavras, o legislador estaria conferindo ao juiz autorização para, por esta via oblíqua,

\footnotetext{
${ }^{49}$ BONDIOLI, Luis Guilherme Aidar (2008, p. 1325).

${ }^{50}$ DIDIER JR., Fredie; JORGE, Flávio Cheim; RODRIGUES, Marcelo Abelha (2006, p. 59).
} 
restringir o direito de ação, o que, evidentemente, é proibido à luz do disposto no inciso XXXV, do artigo 5, da Constituição Federal.

A esse respeito Paulo Roberto de Gouvêa Medina assevera:

\begin{abstract}
Instaurar o processo, mediante o exercício regular do direito de ação, é uma opção do autor, que invoca a prestação jurisdicional ou pede a proteção jurídica. Ao tomar essa iniciativa, o autor não pretende, apenas, que se esbocem as primeiras linhas do processo, mas quer que este seja efetivamente formado, com a plena configuração da relação jurídica processual. E não se trata, obviamente, de um capricho seu, mas do exercício de um direito - o direito de ação - que tem por objeto a prestação jurisdicional. $^{51}$
\end{abstract}

A crítica prossegue, na medida em que se verifica que a justificativa para o indeferimento liminar da petição inicial é a reprodução de sentença de outros processos do juízo dos quais o autor não teria participado. Em suma, embora o autor não tenha participado da formação dos precedentes do juízo, ainda assim a norma autoriza o juiz a utilizá-los para abreviar o processamento normal do feito, com a conseqüente restrição da participação das partes na nova ação.

Em virtude de o legislador ter conferido poderes ao juiz para eliminar etapas processuais, limitando assim a participação do autor e do réu no processo (que se daria com a apresentação de resposta à petição inicial, com oferecimento de réplica - se o caso - pelo autor e, eventualmente, com a produção de provas, caso surgisse tal necessidade), os críticos do dispositivo sustentam que o princípio do contraditório - hoje compreendido como a garantia de efetiva participação em todos os atos processuais passíveis de influir no convencimento do magistrado - restaria violado.

A propósito, sobre o princípio do contraditório, confiram-se as lições do professor português José Lebre de Freitas, reproduzidas por Paulo Medina:

O contraditório implica, fundamentalmente, uma garantia de participação efetiva das partes no desenvolvimento de todo o litígio, mediante a

\footnotetext{
${ }^{51}$ MEDINA, Paulo Roberto de Gouvêa (jul./dez. 2006, p. 87).
} 
possibilidade de, em plena igualdade, influirem em todos os elementos (factos, provas, questões de direito) que se encontrem em ligação com o objeto da causa e que em qualquer fase do processo apareçam como potencialmente relevantes para a decisão. ${ }^{52}$

No plano das questões de direito, o princípio do contraditório exige que, antes da sentença, às partes seja facultada a discussão efectiva de todos os fundamentos de direito em que a decisão se baseie. ${ }^{53}$

Daniel Francisco Mitidiero está entre aqueles que vêem no dispositivo

flagrante afronta ao princípio do contraditório. Sobre o tema, assim se manifesta o autor:

Com efeito, a pretexto de agilizar o andamento dos feitos, pretende o legislador sufocar o caráter dialético do processo, em que o diálogo judiciário, pautado pelos direitos fundamentais, propicia ambiente de excelência para reconstrução da ordem jurídica e conseguinte obtenção de decisões justas. Aniquila-se o contraditório, subtraindo-se das partes 0 poder de convencer o órgão jurisdicional do acerto de seus argumentos. Substitui-se, em suma a acertada combinação de uma legitimação material e processual das decisões judiciais por uma questionável legitimação pela eficiência do aparato judiciário, que, de seu turno, pode facilmente desembocar na supressão do caráter axiológico e ético do processo e de sua vocação para ponto de confluência de direitos fundamentais. ${ }^{54}$

A crítica ao artigo 285-A se torna ainda mais robusta, quando se leva em consideração que o dispositivo legal autoriza o magistrado a tomar como parâmetro para solucionar as demandas repetidas que Ihe forem propostas a sua própria sentença, ou, quando muito, a sentença de outro magistrado que atuou naquele juízo em momento anterior, ao invés, de fundamentar sua decisão em um entendimento mais consolidado, consubstanciado em súmula ou jurisprudência dominante dos tribunais que Ihe são hierarquicamente superiores.

Tudo isso põe em xeque a constitucionalidade do dispositivo e nos leva a perquirir qual foi a intenção do legislador ao criar esta norma e se de alguma forma ela pode sobreviver às alegações de inconstitucionalidade e revelar-se útil ao direito processual civil brasileiro.

\footnotetext{
${ }^{52}$ MEDINA, Paulo Roberto de Gouvêa (jul./dez. 2006, p. 89 - 90).

${ }^{53}$ MEDINA, Paulo Roberto de Gouvêa (jul./dez. 2006, p. 91).

${ }^{54}$ MITIDIERO, Daniel Francisco (2006, p. ).
} 
Sem dúvida, como consta da própria exposição de motivos da Lei 11.277, o escopo do legislador foi conferir racionalidade e celeridade à prestação jurisdicional. Pela sistemática do artigo 285-A, tais objetivos são alcançados pela economia de tempo que se obterá com a dispensa da citação e de outros atos processuais que eventualmente fossem necessários (como a réplica, por exemplo).

Outra forma de alcançar os mesmos objetivos é o proferimento de uma decisão coerente e potencialmente capaz de convencer o autor de que ele não é titular do direito vindicado, sendo inclusive desvantajoso continuar insistindo no processo judicial com a interposição de apelação. Esta segunda forma é muito mais eficaz que a primeira no alcance da tão perseguida celeridade. Isso porque, conformando-se o autor com a sentença proferida, ela transitará livremente em julgado; de outra sorte, caso o autor não se conforme com o julgamento da causa, muito provavelmente irá interpor sucessivos recursos até obter uma decisão favorável.

O ideal, portanto, seria conciliar a técnica do art. 285-A do CPC com o proferimento de uma decisão coerente e potencialmente capaz de convencer o autor de que ele não merece sair vitorioso na causa. Se isto for possível, o desfecho do processo será extremamente rápido e o processo realmente estará dotado dos meios que garantam a celeridade de sua tramitação (art. $5^{\circ}$, LXXVIII). Ilustrando o que acabou de ser dito: o autor ajuizará ação; o juiz proferirá sentença de improcedência prima facie (desde que preenchidos os requisitos para tanto); o autor convencido do acerto da decisão ficará desmotivado a interpor apelação; a sentença, muito provavelmente, transitará em julgado sem que seja ouvido o réu, que será beneficiado pelo julgamento e não haverá motivos para cassar a sentença 
pelo fato de o réu não ter figurado como integrante da relação jurídica processual, já que a sentença não trará prejuízo algum a ele.

Luis Guilherme Aidar Bondioli sustenta que a intenção do legislador não foi apenas a de acelerar o processo por meio da abreviação do procedimento, mas, sobretudo, mediante o proferimento de uma decisão que convença o autor de que ele não merece sair vitorioso na causa e que, com grande probabilidade, transitará em julgado:

No caso, as vantagens vislumbradas pelo legislador atrelam-se à expectativa de que o pronunciamento liminar efetivamente coloque fim ao processo, convencendo o autor da inexistência do direito por ele alegado e desencorajando-o de levar o feito adiante, que, assim, encerrar-se-ia com o menor dispêndio de energia possível e sem a participação do réu. ${ }^{55}$

Evidentemente que para atingir tal desiderato (convencer o autor do acerto do julgamento) o juiz deve dar a sua decisão amparo não apenas nos casos idênticos do juízo, mas, sobretudo, em súmula e jurisprudência dominante dos tribunais que Ihe são hierarquicamente superiores (e, dentre essas duas, principalmente na primeira, que é mais facilmente identificável e menos suscetível de variações).

O fato de o artigo 285-A não impor como requisito que a sentença esteja em consonância com súmula e jurisprudência dominante do tribunal a que pertencer o juiz, de tribunal superior ou do Supremo Tribunal Federal, contudo, não conduz à inconstitucionalidade do dispositivo. Embora o legislador não tenha agido com a prudência devida, consistente em deixar expresso tal requisito, a omissão legislativa pode ser contornada com base nos métodos de interpretação das leis, na nítida valorização da jurisprudência pelo legislador através das recentes leis que alteraram o Código de Processo Civil e na lógica subjacente ao dispositivo.

\footnotetext{
${ }^{55}$ BONDIOLI, Luis Guilherme Aidar (2008, p. 1324).
} 
A interpretação das leis é atividade da maior relevância no mundo jurídico, pois é por meio dela que podemos extrair o sentido da norma e o seu real alcance. A atividade interpretativa não se resume à identificação do sentido literal (ou gramatical) das palavras e frases que compõem um determinado dispositivo legal; a bem da verdade, isso é o pontapé inicial da atividade interpretativa, sendo certo que existem vários outros métodos de interpretação como, por exemplo, o teleológico.

A propósito Humberto Theodoro Júnior ressalta a importância da interpretação teleológica com os seguintes dizeres:

No campo da norma jurídica a interpretação não pode dar-se com o
emprego da técnica própria da lógica formal. Tem-se de procurar, no meio
humano e social, a razão pela qual a lei foi editada, para diante dos
interesses tutelados, compreender quais os fins ou objetivos que pretendeu
alcançar. É isto que a lógica do razoável realiza na tarefa interpretativa da
norma jurídica. Antes de tudo, as normas de Direito devem ser interpretadas
à luz da confrontação de seus efeitos com o propósito que inspirou a
elaboração da norma. ${ }^{56}$ Ora, tendo o legislador concebido a Lei 11.277 com o objetivo de conferir racionalidade à atividade jurisdicional, então, com base em uma leitura teleológica da lei, não se afigura razoável que o magistrado invoque a literalidade do artigo para indeferir liminarmente a petição inicial com base em precedentes do juízo incompatíveis com o entendimento dos tribunais que lhe são hierarquicamente superiores. Agindo dessa forma, o juiz estará contribuindo para a ineficiência do Poder Judiciário, motivando o autor a recorrer da decisão até obter um pronunciamento jurisdicional favorável, ou, ainda, caso não seja interposta apelação, estará colaborando para o incremento de um sistema judiciário que não garante isonomia de resposta a uma mesma questão jurídica e que, conseqüentemente, será incapaz de atender os anseios sociais por justiça.

\footnotetext{
${ }^{56}$ THEODORO JÚNIOR, Humberto (ago. 2007, p. 19).
} 
Ademais, as recentes alterações do Código de Processo Civil deixam clara a preferência do legislador pelos entendimentos sumulados ou amparados por jurisprudência dominante, como se verifica, por exemplo, no parágrafo único do art. 120 (acrescentado pela Lei 9.756/98), no $\S 3^{\circ}$ do art. 475 (incluído pela Lei 10.352/01), no $\S 1^{\circ}$ do art. 518 (adicionado pela Lei 11.276/06), no inciso I do art. 527 com a redação determinada pela Lei 10.352/01 e no art. 557 alterado pela Lei 9.756/98.

Outrossim, a lógica inerente ao dispositivo nos autoriza extrair a conclusão de que a sentença de improcedência prima facie deve, sim, encontrar amparo na jurisprudência consolidada dos tribunais. A rigor, o que realmente justifica a aplicação do artigo 285-A é que a matéria unicamente de direito esteja suficientemente amadurecida e solidificada a ponto de dispensar outras discussões sobre o mesmo tema. Isso só pode ser constatado, quando houver súmula ou jurisprudência dominante dos tribunais hierarquicamente superiores ao juiz acerca do tema objeto de apreciação.

Desse modo, a sentença liminar de improcedência, além de não poder contrariar súmula ou jurisprudência dominante, não poderá ser prolatada se a respeito de determinado tema não houver súmula ou jurisprudência dominante. Em virtude disso, podemos falar na existência de um terceiro requisito - não previsto expressamente na lei, é verdade -, mas de fundamental importância para a adequada aplicação do artigo 285-A do CPC, qual seja: a existência de súmula ou jurisprudência dominante que dê amparo à sentença liminar de improcedência.

Daí porque autores como José Antonio Fichtner e André Luís Monteiro chamam a atenção para a necessidade de verificação de três requisitos e não apenas dois: 
Conforme se demonstrará mais adiante, considera-se, neste texto, que os pressupostos legais para aplicação do mencionado dispositivo são (i) causa versando sobre matéria eminentemente de direito; (ii) existência de precedentes no mesmo juízo com identidade de causas de pedir e pedidos; e (iii) correspondência entre os precedentes do juízo e o entendimento dominante dos tribunais hierarquicamente superiores. A observância estrita desses pressupostos legais, absolutamente compatíveis com o sistema processual constitucional em vigor, deve nortear a atuação do magistrado. ${ }^{57}$

Mais adiante os mesmos autores advertem:

"O julgamento sumário de improcedência não deve ser um capricho do juiz, mas uma resposta do Poder Judiciário - como instituição mesmo - a casos já sobejamente enfrentados e decididos, o que somente resta caracterizado com a formação da jurisprudência dominante dos tribunais hierarquicamente superiores.".58

O indeferimento liminar da petição inicial não deve ser tido como incompatível com o direito de ação e com o princípio do contraditório, como defendem os críticos do art. 285-A do CPC. Cumpridos os requisitos legais (matéria unicamente de direito e reprodução de sentença proferida em precedentes do juízo com o mesmo quadro fático e capaz de afastar todos os fundamentos jurídicos lançados na petição inicial do novo processo e de resolver o mérito com a improcedência de todos pedidos) e, estando a decisão devidamente amparada na jurisprudência consolidada de tribunais, poderá o juiz proferir sentença prima facie sem que isto importe na violação daquele direito e do aludido princípio.

O autor pode lançar, na petição inicial, todos os argumentos que entende úteis para fundamentar a sua pretensão. Ao sentenciar o caso (que versa sobre matéria exclusivamente de direito) o juiz afastará toda fundamentação jurídica do autor e estará se valendo de uma sentença já proferida no juízo e com respaldo em entendimento consolidado na jurisprudência. Em suma, os pedidos do autor não foram indeferidos em um caso qualquer; trata-se de hipótese em que a matéria foi amplamente discutida nos tribunais e sobre a qual já existe entendimento definido

\footnotetext{
${ }^{57}$ FICHTNER, José Antonio e MONTEIRO, André Luís (jul. 2009, p. 51).

${ }^{58}$ FICHTNER, José Antonio e MONTEIRO, André Luís (jul. 2009, p. 58).
} 
em benefício do réu. Daí porque seria viável dispensar a sua citação, abreviando o curso do procedimento.

Oportuno relembrar que a sentença prevista no art. 285-A do CPC não é a única hipótese de julgamento liminar com resolução do mérito. Como visto, a sentença que indefere a petição inicial pela verificação da ocorrência de decadência ou prescrição (art. 295, IV) também resolve o mérito do processo (art. 269, IV), sem que para isso seja necessária a citação do réu.

Acrescente-se aos argumentos expostos que, caso o autor não se conforme com a sentença, seja porque, a seus olhos, não se encontram presentes os requisitos para sua prolação, ou porque seus argumentos jurídicos devem prevalecer, poderá interpor apelação e o juiz poderá retratar-se e determinar o prosseguimento normal do feito com a citação do réu $\left(\S 1^{\circ}\right)$. Não havendo retratação, o réu será citado para responder ao recurso, e o inconformismo do autor será apreciado pelo tribunal $\left(\S 2^{\circ}\right)$.

Por tudo isso, o proferimento da sentença liminar de improcedência desde que cumpridos os requisitos legais (matéria unicamente de direito e existência de sentença de total improcedência em casos idênticos), e, principalmente, que a decisão encontre amparo na jurisprudência dos tribunais hierarquicamente superiores ao juiz - revela-se, em princípio, razoável.

As críticas ao dispositivo, contudo, não se limitam a questionar a possibilidade de o juiz proferir uma sentença prima facie. Prolatada a sentença, surgem novos obstáculos à constitucionalidade do dispositivo que dizem respeito à maneira como o processo haverá de ser conduzido.

Pode-se destacar, por exemplo, que o legislador não prevê que - em havendo o trânsito em julgado da sentença liminar de improcedência em virtude da 
não-interposição de apelação por parte do autor - seja enviada comunicação ao réu, informando a ele que no juízo foi proferida sentença de mérito, que transitou em julgado e que Ihe é favorável. Ora, essa comunicação é importantíssima, pois, caso o autor proponha a mesma ação noutra Vara/Comarca/Circunscrição Judiciária, o réu que não foi comunicado da sentença proferida no processo anterior e que certamente desconhece a sua existência, ficará prejudicado em sua defesa, porquanto não poderá alegar em seu favor a existência de coisa julgada material (art. 301, VI do estatuto processual civil), hipótese em que o processo seria extinto sem resolução do mérito, a teor do que dispõe o inciso $\mathrm{V}$ do artigo 267 do CPC.

Sem dúvida, a ausência de previsão de tal comunicação coloca em risco o princípio da publicidade dos atos processuais (de matriz constitucional - art. 93, IX da CF - e do qual uma das facetas é a publicação da decisão às partes) e dá ensejo à omissão de informação preciosa ao réu, podendo cogitar-se até mesmo na violação do princípio da ampla defesa em futura e eventual demanda judicial que verse sobre o mesmo tema.

Alguns doutrinadores têm procurado superar esse obstáculo com a aplicação analógica do artigo 219, §6º do CPC à hipótese em apreço, em virtude do que seria enviada ao réu notificação do proferimento de sentença de mérito no juízo, já transitada em julgado e que lhe é favorável.

José Miguel Garcia Medina, Luiz Rodrigues Wambier e Teresa Arruda Alvim Wambier, a esse respeito, defendem que:

Embora inexista previsão legal expressa neste sentido, entendemos que se deve aplicar, à hipótese regulada no art. 285-A, o disposto no art. $219, \S 6^{\circ}$, do CPC, segundo o qual, indeferida a petição inicial em razão do reconhecimento da prescrição ou da decadência, "passada em julgado a sentença [...], o escrivão comunicará ao réu o resultado do julgamento". Assim rejeitada a ação por força do art. 285-A, e não tendo o autor apelado contra tal sentença, deverá o réu ser cientificado da existência da ação, 
aplicando-se analogicamente à hipótese o disposto no art. 219 , § $6^{\circ}$, do $\mathrm{CPC}^{59}$

Essa, com efeito, é uma solução perspicaz e bastante razoável para o problema. $\bigcirc \S 6^{\circ}$ do artigo 219 cuida da comunicação do réu em hipótese extremamente parecida à do art. 285-A (qual seja: indeferimento liminar da petição inicial com a improcedência dos pedidos pelo reconhecimento da prescrição), o que justifica a aplicação analógica.

Outra grande crítica direcionada ao dispositivo em exame - e esta, talvez, seja a mais grave de todas - está atrelada ao processamento da apelação. Toda a disciplina legal que o legislador destinou para regular o procedimento após o julgamento imediato da causa está disposta nos breves $\S \S 1^{\circ}$ e $2^{\circ}$ do dispositivo.

Ao $\S 1^{\circ}$ foi dada a seguinte redação: "Se o autor apelar, é facultado ao juiz decidir, no prazo de 5 (cinco) dias, não manter a sentença e determinar o prosseguimento da ação."

Aqui foi conferido ao magistrado o poder para retratar-se da sentença proferida e determinar o processamento regular da ação, como se ela não tivesse sido prolatada. O réu será citado e terá a sua disposição todos os instrumentos que o ordenamento disponibiliza para sua defesa. Nisso não há nenhuma inconstitucionalidade. Aliás, o legislador foi prudente ao prever no $\S 1^{\circ}$ a possibilidade de retratação da sentença, haja vista que a aplicação do art. 285-A deve ser realizada de modo excepcional, ou seja, apenas para os casos que comportem sua incidência, sob pena de serem violados importantes princípios e garantias do processo judicial.

Em relação ao $\S 1^{\circ}$ são válidas duas observações. Em primeiro lugar, o prazo de 5 (cinco) dias, como bem observa Fernanda Guedes Pinto, é um prazo

\footnotetext{
${ }^{59}$ MEDINA, José Miguel Garcia; WAMBIER, Luiz Rodrigues; WAMBIER, Teresa Arruda Alvim (2006, p. 65).
} 
impróprio, não sujeito, assim, à preclusão temporal (sua inobservância pelo juiz não Ihe retirará a faculdade de se retratar da sentença). Na praxe esse prazo é praticamente impossível de ser cumprido, já que, a rigor, o juiz teria que analisar o apelo até cinco dias de sua propositura, o que é sabidamente difícil de ocorrer, principalmente nos juízos com grande volume de demanda. Por isso entendemos que esse juízo de retratação deve ser feito quando da primeira decisão do juiz nos autos após oferecimento da apelação. ${ }^{60}$

Em segundo lugar, é necessária a motivação da decisão. O juiz deve revelar as razões que o levaram a mudar de entendimento; deve mostrar os fundamentos que amparam a nova decisão, afinal, como bem destaca Luis Guilherme Aidar Bondioli, trata-se da retirada do cenário jurídico de um pronunciamento definitivo sobre o meritum causae. Pronunciamentos dessa natureza não podem desaparecer injustificadamente, sob pena de se comprometer a segurança e a estabilidade que devem ser transmitidas pelas decisões judiciais. ${ }^{61}$

Os problemas que dizem respeito ao processamento da apelação surgem no $\S 2^{\circ}$, que está redigido assim: " $\S 2^{\circ}$ Caso seja mantida a sentença, será ordenada a citação do réu para responder ao recurso".

Como é cediço, a citação abre ao réu a possibilidade de apresentar toda a matéria de que disponha para sua defesa, direito esse que pode ser exercido sob as mais diversas formas. Dentre elas é possível mencionar: (a) o oferecimento de contestação, de exceção (de incompetência, impedimento e suspeição) e de reconvenção, conforme faculta o art. 297 do CPC; (b) a impugnação ao valor da causa ex vi do art. 261; e (c) a impugnação ao benefício da assistência judiciária gratuita, nos termos do art. $4^{\circ}, \S 2^{\circ}$ da Lei 1.060/1950.

\footnotetext{
${ }^{60}$ PINTO, Fernanda Guedes (ago. 2007, p. 147).

${ }^{61}$ BONDIOLI, Luis Guilherme Aidar (2008, p. 1326).
} 
Entretanto, segundo a literalidade do $\S 2^{\circ}$ do art. 285-A o réu será citado para responder ao recurso de apelação e não para apresentar, como é de praxe, resposta à petição inicial. Em outras palavras, o réu haverá de trazer a juízo, se assim desejar, as contra-razões de apelação, que constituem instrumento processual por meio do qual o apelado procura combater os argumentos lançados pelo apelante para cassação ou reforma da sentença. Esta circunstância tem preocupado a doutrina, pois a matéria que pode ser alegada nas contra-razões é sensivelmente menor do que a matéria passível de ser apresentada na resposta à petição inicial, do que resultaria inequívoca violação ao princípio da ampla defesa.

Alguns doutrinadores ${ }^{62}$ defendem a tese de que o réu, citado para responder ao recurso, deve, nesta oportunidade, apresentar toda matéria de que dispuser para promover a sua defesa, se antecipando a um eventual entendimento desfavorável por parte do tribunal. Essa tese, que faculta ao tribunal reformar a sentença e atribuir o bem da vida ao autor, encontraria respaldo no art. 515 , $\S 3^{\circ}$. Todavia, ela traz inúmeros inconvenientes e é certo que o legislador não dedicou uma palavra sequer a toda gama de possibilidades que daí podem advir.

Em princípio, o processamento das exceções (arts. 307 a 314), da impugnação do valor da causa (art. 261) e da impugnação do benefício da assistência judiciária gratuita compete ao juiz de primeiro grau, o que traria o inconveniente de, em meio à fase recursal, o juiz ter que decidir questões paralelas recém-alegadas pelo réu/apelado e que, ao final, também poderiam ser objeto de outros recursos. Até parece um contrassenso suscitar nas contra-razões algo que deva ser decidido pelo juiz.

\footnotetext{
${ }^{62}$ Confira-se por todos os ensinamentos de Luis Guilherme Aidar Bondioli: BONDIOLI, Luis Guilherme Aidar. O julgamento liminar de improcedência da demanda da ótica do réu: (art. 285-A). In: Direito civil e processo: estudos em homenagem ao professor Arruda Alvim. São Paulo: Revista dos Tribunais, 2008, p. 1323-1332.
} 
Dificuldade ainda maior diz respeito à reconvenção. Aliás, o réu fica completamente impossibilitado de oferecê-la. O juiz de $1^{\circ}$ grau, que é o competente para julgar a reconvenção (art. 109 do CPC), já proferiu sentença initio litis, sendo de todo inviável o julgamento da reconvenção, que haveria de ser julgada na mesma sentença da ação principal, conforme determina o art. 318 do CPC.

Com efeito, esses são vários óbices à tese de que o réu deve apresentar, logo na primeira oportunidade que tiver para falar nos autos, toda a matéria de que dispuser para sua defesa. O legislador ficou silente em relação a todos os obstáculos apresentados, o que exigiria do intérprete da lei um esforço escomunal para tentar dar uma solução ótima a todos os problemas detectados (e outros que eventualmente forem detectados nesta árdua tarefa) e provavelmente não lograria bom êxito nesta empreitada.

Paradoxalmente, não se pode retirar do réu as modalidades de defesa de que ele pode se valer para defender seus interesses, sob pena de flagrante inconstitucionalidade (violação ao princípio da ampla defesa).

Ao artigo 285-A do CPC, contudo, resta uma escapatória: o $\S 2^{\circ}$ deve ser interpretado na singela redação que Ihe foi conferida, ou seja, o réu será citado não para apresentar toda a matéria de defesa, mas tão-somente para responder ao recurso; além disso, o tribunal, em nenhuma hipótese, poderá reformar a sentença, atribuindo o bem da vida ao autor, porque ao réu não foi garantida ampla defesa, com os meios e recursos a ela inerentes (art. $5^{\circ}$, LV). Por isso, caso o tribunal se incline pela reforma da decisão, deverá cassar a sentença, determinando o retorno dos autos à $1^{\mathrm{a}}$ instância, hipótese em que será facultada ao réu a apresentação de toda matéria de defesa, conforme autoriza a legislação processual. Com essa sistemática será garantida ao réu adequada participação na fase recursal e 
amplitude de defesa junto ao juízo a quo, na hipótese de ser cassada a sentença liminar de improcedência.

Nessa mesma linha de raciocínio, Humberto Theodoro Júnior assevera:

\begin{abstract}
Em seu julgamento, o tribunal poderá manter a decisão de primeiro grau, negando provimento à apelação. Não será possível, porém, reformá-la, no todo ou em parte, porque não cabe no julgamento prima facie entrar no mérito da causa para acolher o pedido, nem mesmo parcialmente, porque isto quebraria o contraditório em desfavor do demandado, que ainda não teve oportunidade de produzir sua contestação. ${ }^{63}$
\end{abstract}

Dada a excepcionalidade do julgamento imediato do mérito nos termos do art. 285-A, o processamento da apelação há de seguir uma sistemática toda peculiar que passaremos a expor.

O autor, contra quem for proferida sentença liminar de improcedência, poderá interpor apelação no prazo de 15 (quinze) dias conforme prevê o art. 508 do CPC. Na apelação, caberá ao apelante requerer ao juiz que se retrate da sentença proferida $\left(\S 1^{\circ}\right)$, e mostrar ao tribunal que o ato impugnado deve ser cassado, por não estarem presentes um ou mais requisitos para o julgamento imediato da causa: matéria unicamente de direito, existência no juízo de sentença de total improcedência em outros casos idênticos e que o entendimento judicial encontre respaldo em súmula ou jurisprudência dominante de tribunais.

Verificando o autor que os três requisitos foram cumpridos pelo magistrado, ainda assim poderá oferecer apelação, apresentando os argumentos pelos quais a sua tese jurídica deve prevalecer, muito embora a jurisprudência esteja afinada à tese contrária. O apelo feito nesses termos também é viável, afinal a jurisprudência está sujeita a variações com o passar do tempo. Isso porá à prova o entendimento jurisprudencial, colaborando para que ele, ao final, saia ainda mais fortalecido ou permitindo que o tribunal, ao analisar os ponderados argumentos do

\footnotetext{
${ }^{63}$ THEODORO JÚNIOR, Humberto (2009, p. 353).
} 
autor, reflita melhor sobre a hipótese e, quiçá, dê-lhe razão ${ }^{64}$, iniciando um movimento de mudança do entendimento jurisprudencial. É bom que o direito mescle sempre segurança (previsibilidade das decisões) com possibilidade de mudança, pois, assim, o direito será capaz de garantir estabilidade às relações sociais e poderá adequar-se às necessidades de cada momento histórico.

Caso o juiz não se retrate, será determinada a citação do réu, que poderá apresentar contra-razões ao recurso no prazo de 15 (quinze) dias (art. 508). Na resposta ao recurso, o réu poderá alegar: (a) ausência dos pressupostos recursais; (b) que seria admissível o indeferimento da petição inicial por alguma das formas previstas no art. 295 do CPC; e (c) que foram devidamente cumpridos todos os requisitos para a aplicação do art. 285-A, devendo a sentença ser mantida.

O tribunal não admitirá a apelação, se não estiverem presentes os pressupostos recursais. Estando presentes os pressupostos recursais verificará a ocorrência de alguma das hipóteses previstas no art. 295 que importe na extinção do processo sem julgamento do mérito (incisos I,II, III, V, VI do caput e parágrafo único). Não sendo caso de extinção do processo sem julgamento do mérito verificará a ocorrência de prescrição ou de decadência (art. 295, IV), hipótese em que deverá julgar improcedentes os pedidos do autor.

Não ocorrendo prescrição nem decadência, o tribunal verificará se estão presentes os requisitos para aplicação do art. 285-A. José Antonio Fichtner e André Luís Monteiro vislumbram nesse momento quatro hipóteses para o julgamento da apelação, que adotamos no presente trabalho monográfico, para melhor expor o tema: (a) a sentença recorrida não preenche os requisitos literalmente exigidos pelo

\footnotetext{
${ }^{64}$ Como afirmado anteriormente, caso o tribunal se incline para a reforma da decisão deverá cassar a decisão proferida em $1^{\circ}$ grau de jurisdição e determinar o retorno dos autos à $1^{\mathrm{a}}$ instância para o regular processamento do feito. Jamais poderá reformar, no todo ou em parte, a sentença, julgando procedente algum ou alguns dos pedidos formulados na inicial.
} 
art. 285-A do estatuto processual; (b) a sentença recorrida, apesar de preencher a literalidade do dispositivo em comento, aborda matéria ainda não pacificada na jurisprudência dos tribunais hierarquicamente superiores; (c) a sentença recorrida, apesar de preencher a literalidade do dispositivo em análise contraria a jurisprudência dos tribunais hierarquicamente superiores; e (d) a sentença recorrida preenche os requisitos exigidos pelo art. 285-A do Código de Processo Civil e está de acordo com a jurisprudência dos tribunais hierarquicamente superiores a respeito da matéria. ${ }^{65}$

Nas três primeiras hipóteses, o tribunal deverá cassar a sentença, porquanto não foram atendidos todos os requisitos para o julgamento imediato de improcedência; os autos retornarão ao $1^{\circ}$ grau de jurisdição, quando será facultada ao réu a apresentação de todas as modalidades de defesa, conforme lhe faculta a lei processual.

$\mathrm{Na}$ última hipótese, em virtude de estarem presentes todos os pressupostos para aplicação do dispositivo em comento, o tribunal deverá manter a sentença, salvo se, fundamentadamente, optar pela revisão da jurisprudência consolidada na própria corte. Em sendo mantida a sentença, não haverá prejuízo algum para o réu, que sairá vencedor, e, não havendo interposição de recurso, o acórdão transitará livremente em julgado. Caso o tribunal, verificando que a sua jurisprudência para o caso em questão não se revela mais apta a atender aos novos anseios sociais, opte pela sua revisão, deverá cassar a sentença proferida.

Vários autores ${ }^{66}$ sustentam, com propriedade, a possibilidade de o juiz não receber a apelação caso a sentença liminar de improcedência esteja amparada

\footnotetext{
${ }^{65}$ FICHTNER, José Antonio e MONTEIRO, André Luís (jul. 2009, p. 62).

${ }^{66}$ Entre eles é possível mencionar: José Miguel Garcia Medina, Luiz Rodrigues Wambier e Teresa Arruda Alvim Wambier; José Antonio Fichtner e André Luís Monteiro; Fernanda Guedes Pinto; Luciano Viana Araújo.
} 
em súmula do Superior Tribunal de Justiça ou do Supremo Tribunal Federal, a teor do art. 518, $\S 1^{\circ}$ do CPC. Nessa hipótese, caberia agravo de instrumento contra a decisão interlocutória (art. 522 do CPC).

Questões de ordem pública, tal como a alegação de incompetência absoluta (art. 113), podem e devem ser alegadas pelas partes na fase recursal e caberá ao tribunal analisá-las.

Por fim, cumpre frisar que o surgimento de matéria que exija dilação probatória obrigará o Tribunal a cassar a sentença proferida em virtude do nãoatendimento de um dos requisitos para sua prolação (matéria unicamente de direito).

Vista a sistemática que envolve a apelação, poderia se indagar se o art. 285-A não estaria na contramão do princípio da celeridade, porquanto dá ensejo à interposição de apelação de cujo julgamento poderá resultar a cassação da sentença e o retorno dos autos ao $1^{\circ}$ grau de jurisdição, retomando-se o processamento do feito desde o início com a apresentação de defesa por parte do réu.

Tal indagação, todavia, não há de prosperar. Ora, como defendemos, a aplicação do artigo 285-A apenas é possível quando o magistrado puder proferir sentença liminar de improcedência que encontre respaldo em súmula ou jurisprudência dominante dos tribunais que Ihe são superiores. Ao julgar a causa, o juiz haverá de indicar a súmula ou jurisprudência dominante que ampara a sentença. Em virtude disso, o autor, certamente, ficará menos motivado a recorrer do julgamento initio litis; como resultado, espera-se que, para um quantitativo considerável de processos, a sentença prima facie transite livremente em julgado, promovendo celeridade aos julgamentos. 
De qualquer modo, ainda que seja oferecida a apelação, a tendência natural do julgamento será a de manter a sentença, porquanto a aplicação escorreita do dispositivo exige que o juiz embase o seu entendimento em súmula ou jurisprudência dominante de tribunais. Nesse sentido, a aludida produção de sentenças inválidas a exigir subseqüentes cassações pelo tribunal certamente ocorrerão na minoria dos casos, não sendo exagerado admitir-se que os ganhos em celeridade com o proferimento da sentença liminar de improcedência serão consideravelmente maiores que os eventuais atrasos na tramitação processual decorrentes da má aplicação do dispositivo.

Com efeito, como se pôde observar ao longo da exposição, várias são as críticas direcionadas ao artigo 285-A no que diz respeito a sua constitucionalidade. Contudo, tomadas as cautelas necessárias, é possível preservar o artigo e por meio dele conferir mais celeridade ao processo judicial, sem que de sua aplicação resulte violação dos direitos, garantias e princípios constitucionais do processo.

Para tanto, o magistrado deve agir com prudência; deve obedecer com rigor aos requisitos necessários à aplicação do art. 285-A (que são em número de três e não apenas dois como decorreria de uma interpretação literal do caput do artigo); deve estar atento para a obrigatoriedade da notificação do réu, caso a sentença liminar de improcedência transite em julgado, em virtude da não interposição de apelação por parte do autor. O tribunal, por seu turno, deverá julgar a apelação sempre consciente de que o acórdão jamais poderá reformar a sentença para dar ganho de causa ao autor, sob pena de violação do princípio da ampla defesa. 


\section{Conclusões}

A presente monografia teve como objeto de estudo a análise da constitucionalidade do art. 285-A do Código de Processo Civil. A fim de dar suporte ao tema escolhido, procurou-se reforçar a importância do direito de acesso à justiça, o dever do Estado de prestar a atividade jurisdicional com celeridade e efetividade e a incessante busca do legislador pelo alcance desses fins, que resultou na realização de inúmeras reformas no estatuto processual civil, dentre as quais está a criação do art. 285-A do CPC.

No primeiro capítulo, foi evidenciada a substituição, no desenrolar histórico, da justiça privada (exercida pelos particulares e incapaz de assegurar plenamente a paz social) pela justiça pública (exercida pelo Estado). Como fruto dessa mudança, nasceu para o particular o direito de acesso à justiça. O Estado, por sua vez, assumiu o encargo de prestar uma jurisdição efetiva.

O conceito "celeridade" foi apresentado como atributo imanente e indissociável do conceito de jurisdição efetiva. Sem dúvida, a atividade jurisdicional deve ser prestada com celeridade; a morosidade da tutela compromete o sentido reparador da decisão judicial, definhando lentamente o direito do titular da posição jurídica de vantagem.

Todavia, daí não se pode tirar a conclusão de que o princípio da celeridade pode ser buscado a todo custo. Esse princípio, como todo e qualquer princípio, não é absoluto, devendo compatibilizar-se com os demais princípios do ordenamento jurídico.

No segundo capítulo, discorreu-se sobre a morosidade do Poder Judiciário e mostrou-se o recente e taludo movimento de reformas do Código de 
Processo Civil, inspirado no ideal de promoção de uma tutela jurisdicional mais célere e efetiva. Dentre as inúmeras alterações do estatuto processual, exsurgiu a Lei 11.277/2006, que introduziu o artigo 285-A ao CPC e chama atenção em virtude das grandes discussões que giram em torno de sua constitucionalidade.

Destacou-se a importância das normas constitucionais (especialmente dos princípios encartados na Lei Maior) no controle de constitucionalidade das leis e, dentro desse cenário propício, passou-se propriamente ao objetivo central do trabalho, qual seja: o exame da constitucionalidade do artigo 285-A do CPC, do qual foi possível extrair algumas conclusões.

Não são poucas as críticas direcionadas ao dispositivo em apreço. As principais alegações de inconstitucionalidade do dispositivo estão relacionadas ao direito de ação e aos princípios do contraditório, da ampla defesa, e do devido processo legal.

Embora o caput do dispositivo em comento aluda apenas a dois requisitos (matéria unicamente de direito e existência de sentença de total improcedência em outros casos idênticos), o artigo exige, ainda, um terceiro e fundamental requisito, a saber: que a sentença liminar de improcedência encontre respaldo em súmula ou jurisprudência dominante do tribunal a que pertencer o juiz, de tribunal superior, ou do Supremo Tribunal Federal.

Verificando a presença desses três requisitos, o juiz poderá rejeitar de plano os pedidos do autor e disso não resultará violação ao direito de ação nem ao princípio do contraditório. Aliás, neste caso, é até aconselhável que o juiz profira sentença liminar de improcedência, porquanto a matéria encontra-se sobejamente debatida e com solução definida em sede jurisprudencial. 
Espera-se que, em boa parte das ações, a sentença liminar de improcedência transite livremente em julgado, uma vez que a aplicação adequada do dispositivo - que exige que a sentença do magistrado encontre amparo no entendimento dominante dos tribunais que lhe são hierarquicamente superiores desestimulará o oferecimento de apelação.

Transitando em julgado o decisum, o réu deverá ser comunicado do resultado do julgamento, aplicando-se por analogia o art. 219, $\S 6^{\circ}$ do CPC. Neste caso, haverá inequívocos ganhos na celeridade dos julgamentos. Além disso, o réu receberá uma tutela integral, sem ter que arcar com qualquer despesa processual, e sem experimentar o desgaste emocional decorrente da participação no processo.

Havendo apelação, o réu poderá apresentar contra-razões, ficando-lhe assegurada adequada participação na fase recursal. Ademais, seu direito à apresentação de toda matéria de defesa junto ao juízo de $1^{\circ}$ grau de jurisdição estará garantido, porquanto o tribunal não poderá reformar a sentença, atribuindo o bem da vida ao autor, mas apenas cassá-la.

Vê-se, assim, que é perfeitamente possível compatibilizar o artigo 285-A do CPC com os princípios, direitos e garantias constitucionais do processo. Afigurase, pois, viável e até mesmo conveniente a preservação do preceito normativo, cuja correta aplicação deixará resguardados o direito de ação, os princípios do contraditório, da ampla defesa e do devido processo legal, além do que permitirá bons ganhos em termos de celeridade processual. 


\section{Referências bibliográficas}

ALVIM, José Eduardo Carreira. Teoria geral do processo. $13^{a}$ ed., Rio de Janeiro: Editora Forense, 2010.

ARAUJO, Luciano Vianna. Art. 285-A do CPC (julgamento imediato, antecipado e maduro da lide): evolução do sistema desde o Código de processo civil de 1939 até 2007. Artigo de Revista. In: Revista de processo, v. 33, n. 160, p. 157-179, jun. 2008.

BANCO MUNDIAL. Fazendo com que a justiça conte: medindo e aprimorando o desempenho do judiciário no Brasil. Relatório. Banco Mundial, 2004.

BARROSO, Luís Roberto. Fundamentos teóricos e filosóficos do novo direito constitucional brasileiro (pós-modernidade, teoria crítica e póspositivismo). In: A nova interpretação constitucional: ponderação, direitos fundamentais e relações privadas. $3^{a}$ ed. revista. Rio de Janeiro: renovar, 2008, p. $1-48$.

BONDIOLI, Luis Guilherme Aidar. 0 julgamento liminar de improcedência da demanda da ótica do réu: (art. 285-A). In: Direito civil e processo: estudos em homenagem ao professor Arruda Alvim. São Paulo: Revista dos Tribunais, 2008, p. 1323-1332.

BUENO, Cassio Scarpinella. A nova etapa da reforma do Código de processo civil. $2^{\mathrm{a}}$ ed. revista, atualizada e ampliada, v. 2, São Paulo: Saraiva, 2006.

CÂMARA, Alexandre Freitas. Lições de direito processual civil. Rio de Janeiro: Lumen Juris, 2009. v 1. 
CANOTILHO, José Joaquim Gomes. Direito constitucional e teoria da constituição. Coimbra: Almedina, 2002.

CAPPELLETTI, Mauro e GARTH, Bryant. Acesso à Justiça. Tradução e revisão de Ellen Gracie Northfleet. Porto Alegre: Ségio Antonio Fabris Editor, 2002.

DIDIER JR., Fredie; JORGE, Flávio Cheim; RODRIGUES, Marcelo Abelha. A terceira etapa da reforma processual civil: comentários às leis $\mathbf{n}$. 11.187 e 11.232, de 2005; 11.276, 11.277 e 11.280, de 2006. São Paulo: Saraiva, 2006.

DWORKIN, Ronald. Levando os direitos a sério. Tradução: Nelson Boeira. São Paulo: Martins Fontes, 2010.

FARIA, José Eduardo. Direito e justiça no século XXI. Texto apresentado no Seminário Direito e Justiça no Século XXI. Coimbra: Centro de Estudos Sociais, 2003.

FICHTNER, José Antonio e MONTEIRO, André Luís. Sentença de julgamento imediato do mérito: algumas considerações sobre o art. 285-A do CPC. Artigo de revista. In: Revista dialética de direito processual, n. 76, p. 48-65, jul. 2009.

LEAL, Luciana de Oliveira. $\mathbf{O}$ acesso à justiça e a celeridade na tutela jurisdicional. Artigo de revista. In: Revista de Direito do Tribunal de Justiça do Estado do Rio de Janeiro, n. 65, p. 40-55, out./dez. 2005.

LUCCA, Rodrigo Ramina de. Resolução liminar do mérito. Artigo de Revista. In: Revista Dialética de Direito Processual, n. 79, p. 115-135, out. 2009.

MAGNO, Fádua Maria Drumond Chequer. Uma análise acerca da constitucionalidade do art. 285-A do CPC em face dos princípios do devido 
processo legal e do contraditório. Artigo de revista. In: De Jure: revista jurídica do Ministério Público do Estado de Minas Gerais, n. 13, p. 275-291, jul./dez. 2009.

MARINONI, Luiz Guilherme. Artigo 5º, inciso LXXVIII: a todos, no âmbito judicial e administrativo, são assegurados a razoável duração do processo e os meios que garantam a celeridade de sua tramitação. In: Comentários à constituição federal de 1988. $1^{\text {a }}$ ed. Rio de Janeiro: Editora Forense, 2009, p. 309-325.

MEDINA, José Miguel Garcia; WAMBIER, Luiz Rodrigues; WAMBIER, Teresa Arruda Alvim. Breves comentários à nova sistemática processual civil. São Paulo: Revista dos Tribunais, 2006.

MEDINA, Paulo Roberto de Gouvêa. Sentença emprestada: uma nova figura processual. Artigo de revista. In: Revista da Ordem dos Advogados do Brasil, v. 36, n. 83, p. 85-94, jul./dez. 2006.

MENDES, Aluisio Gonçalves de Castro. O poder judiciário no Brasil. In: Direito civil e processo: estudos em homenagem ao professor Arruda Alvim. São Paulo: Revista dos Tribunais, 2008, p. 962-980.

MENDES, Gilmar Ferreira; COELHO, Inocêncio Mártires; e BRANCO, Paulo Gustavo Gonet. Curso de Direito Constitucional. $2^{\mathrm{a}}$ ed. revista e atualizada. São Paulo: Saraiva, 2008.

MENDONÇA JUNIOR, Delosmar. Princípio constitucional da duração razoável do processo. In: Direito civil e processo: estudos em homenagem ao professor Arruda Alvim. São Paulo: Revista dos Tribunais, 2008. p. 989-1000.

MIRANDA, Pontes de. Comentários ao Código de Processo Civil, tomo 1, arts. $1^{\circ}$ a $45.5^{\mathrm{a}}$ ed., Rio de Janeiro: Editora Forense, 1996. 
MITIDIERO, Daniel Francisco. Comentários ao Código de processo civil. Tomo III. São Paulo: Memória Jurídica, 2006.

MONTENEGRO FILHO, Misael. Princípio da inafastabilidade da jurisdição. In: Comentários à constituição federal de 1988. $1^{\mathrm{a}}$ ed. Rio de Janeiro: Editora Forense, 2009, p. 172-175.

PANTOJA, Fernanda Medina. Reformas processuais: sistematização e perspectivas. Artigo de Revista. In: Revista de processo, v. 33, n. 160, p. 87-114, jun. 2008.

PEREZ, Augusto Martinez e ROMEU, Luciana Campanelli. Os arts. 518 e 285-A do Código de processo civil e a superação da morosidade. Artigo de revista. In: Revista CEJ, v. 7, n. 42, p. 23-39, jul./set. 2008.

PINTO, Fernanda Guedes. As ações repetitivas e o novel art. 285-A do CPC: (racionalização para as demandas de massa). Artigo de revista. In: Revista de Processo, v. 32, n. 150, p. 121-157, ago. 2007.

SILVA, Bruno Freire e. A busca de um modelo de prestação jurisdicional efetiva: tendências do processo civil contemporâneo. In: Direito civil e processo: estudos em homenagem ao professor Arruda Alvim. São Paulo: Revista dos Tribunais, 2008, p. 981-988.

THEODORO JÚNIOR, Humberto. Curso de direito processual civil. 50a ed., v. 1, Rio de Janeiro: Editora Forense, 2009.

THEODORO JÚNIOR, Humberto. Interpretação e aplicação das normas jurídicas. Artigo de revista. In: Revista de Processo, v. 32, n. 150, p. 11-23, ago. 2007.

VIANA, Ulisses Schwarz. Repercussão geral: sob a ótica da teoria dos sistemas de Niklas Luhmann. São Paulo: Saraiva, 2010. 
ZAVASCKI, Teori Albino. Medidas cautelares e medidas antecipatórias: Técnicas diferentes, função constitucional semelhante. In: Inovações do Código de Processo Civil. Livraria do Advogado. Porto Alegre: 1997. 